\title{
Early embryogenesis and organogenesis in the annelid Owenia fusiformis
}

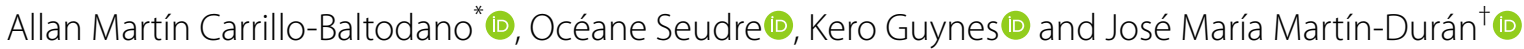

\begin{abstract}
Background: Annelids are a diverse group of segmented worms within Spiralia, whose embryos exhibit spiral cleavage and a variety of larval forms. While most modern embryological studies focus on species with unequal spiral cleavage nested in Pleistoannelida (Sedentaria + Errantia), a few recent studies looked into Owenia fusiformis, a member of the sister group to all remaining annelids and thus a key lineage to understand annelid and spiralian evolution and development. However, the timing of early cleavage and detailed morphogenetic events leading to the formation of the idiosyncratic mitraria larva of $O$. fusiformis remain largely unexplored.

Results: Owenia fusiformis undergoes equal spiral cleavage where the first quartet of animal micromeres are slightly larger than the vegetal macromeres. Cleavage results in a coeloblastula approximately $5 \mathrm{~h}$ post-fertilization (hpf) at $19^{\circ} \mathrm{C}$. Gastrulation occurs via invagination and completes $4 \mathrm{~h}$ later, with putative mesodermal precursors and the chaetoblasts appearing $10 \mathrm{hpf}$ at the dorso-posterior side. Soon after, at $11 \mathrm{hpf}$, the apical tuft emerges, followed by the first neurons (as revealed by the expression of elav 1 and synaptotagmin-1) in the apical organ and the prototroch by $13 \mathrm{hpf}$. Muscles connecting the chaetal sac to various larval tissues develop around $18 \mathrm{hpf}$ and by the time the mitraria is fully formed at $22 \mathrm{hpf}$, there are FMRFamide ${ }^{+}$neurons in the apical organ and prototroch, the latter forming a prototrochal ring. As the mitraria feeds, it grows in size and the prototroch expands through active proliferation. The larva becomes competent after $\sim 3$ weeks post-fertilization at $15^{\circ} \mathrm{C}$, when a conspicuous juvenile rudiment has formed ventrally.

Conclusions: Owenia fusiformis embryogenesis is similar to that of other equal spiral cleaving annelids, supporting that equal cleavage is associated with the formation of a coeloblastula, gastrulation via invagination, and a feeding trochophore-like larva in Annelida. The nervous system of the mitraria larva forms earlier and is more elaborated than previously recognized and develops from anterior to posterior, which is likely an ancestral condition to Annelida. Altogether, our study identifies the major developmental events during $O$. fusiformis ontogeny, defining a conceptual framework for future investigations.
\end{abstract}

Keywords: Spiral cleavage, Equal cleavage, Larva, Mitraria, Trochophore, Nervous system, Neural development, Spiralia, Annelida, Owenia fusiformis

*Correspondence: a.carrillo-baltodano@qmul.ac.uk

†José María Martín-Durán-Senior author

School of Biological and Chemical Sciences, Queen Mary University of London, London E1 4NS, UK

\section{Background}

Annelids are a diverse and abundant group of segmented worms, part of the larger clade of bilaterian animals called Spiralia [1, 2]. Ancestral to annelids is the presence of the quartet spiral cleavage program during early embryonic development, in which blastomeres divide obliquely and perpendicular to the animal-vegetal axis from the 4-cell stage onwards, alternating directions and 
giving as a result the stereotypical spiral-like arrangement of the embryonic cells when looked from above [3-7]. Most modern molecular studies of annelid embryogenesis have focused on species belonging to the two most diverse groups, namely Sedentaria (e.g., the capitellid Capitella teleta, the leech Helobdella robusta and the serpulids Hydroides elegans and Spirobranchus lamarcki) and Errantia (e.g., the nereidid Platynereis dumerilii), which together form Pleistoannelida [4, 8-10] (Fig. 1a). However, the current annelid phylogeny shows Pleistoannelida as a deeply nested clade, with up to five intermediate lineages between this group and the last common annelid ancestor [11-13] (Fig. 1a). Therefore, investigating these other early branching lineages, and in particular Palaeoannelida (Oweniidae + Magelonidae) as the sister taxon to all other annelids (Fig. 1a), is fundamental to uncover the origins and early diversification of Annelida $[12,14,15]$.

Embryological studies in Palaeoannelida are, however, rare and have mostly centered on the genus Owenia. Wilson [16] focused on morphological descriptions of the idiosyncratic mitraria larva up to metamorphosis in Owenia fusiformis Delle Chiaje, 1844, without providing much information about embryogenesis. Early development has only been described for Owenia collaris Hartman, 1955 from the North West Pacific [17], which exhibits equal spiral cleavage and gastrulation via invagination. Later studies on the serotonergic and FMRFamidonergic nervous system were carried out in $O$. fusiformis [14], preliminarily describing the larval nervous system as a complex of a few neurons and axons that develop relative late in the mitraria $(\sim 48 \mathrm{~h}$ post-fertilization). Recently, a set of studies analyzing the expression of the genetic toolkit responsible for axial identity and germ layer specification established $O$. fusiformis as the reference and more tractable research species for molecular investigations within Palaeoannelida $[15,18$, 19] (Fig. 1b-d). However, the early development of $O$. fusiformis has not been described yet, and a systematic and detailed description of the major morphogenetic events after gastrulation and during larval development is lacking.

Here, we combine confocal laser-scanning microscopy and immunostainings, with cell proliferation assays and gene expression analyses to provide a highresolution characterization of the embryonic development and larval growth of O. fusiformis (Fig. 1b-e). We identify the onset of major developmental events in $O$. fusiformis, describing cleavage, gastrulation and organogenesis (myogenesis, neurogenesis, chaetogenesis and ciliogenesis) and establishing morphological and molecular landmarks that define a consistent staging system for this annelid species (Fig. 1e). Altogether, our study contributes to a more systematic and comprehensive understanding of the embryonic development of $O$. fusiformis and Palaeoannelida generally, which proves essential to better reconstruct ancestral developmental traits to Annelida and Spiralia.

\section{Results}

\section{Spiral cleavage}

Females of O. fusiformis spawn small oocytes $(\sim 100 \mu \mathrm{m})$ that are flat and exhibit a conspicuous germinal vesicle (Fig. 2a). Oocyte activation occurs naturally in sea water, resulting in the germinal vesicle breaking down and the oocytes becoming more spherical and receptive to sperm. After fertilization, the zygote (Fig. 2b) takes about $30-60 \mathrm{~min}$ at $19^{\circ} \mathrm{C}$ to extrude the polar bodies and undergo the first holoblastic cleavage, which produces two blastomeres of equal size (Fig. 2c). Within $30 \mathrm{~min}$, the 2-cell embryo divides again symmetrically and dextrally, and by $1.5 \mathrm{~h}$ post-fertilization (hpf) the second zygotic division generates four equal blastomeres, two of which share a vegetal cross furrow (Fig. $2 \mathrm{~d}-\mathrm{f}$ ). Half an hour later ( $2 \mathrm{hpf}$ ), the 4-cell stage embryo divides dextrally and perpendicular to the animal-vegetal axis to form the first quartet of animal micromeres (1q) and four vegetal macromeres (1Q) (Fig. 2g-i). Different to most other annelids, but similar to $O$. collaris [17], sipunculans [20] and nemerteans $[21,22], 1 q$ is slightly larger than the vegetal macromeres (Fig. 2i). Rapidly, the 8-cells stage embryo cleaves sinistrally, giving rise to the second micromere quartet (2q), and the $1 q^{1}$ and $1 q^{2}$ tiers of micromeres $\left(1 q^{1}\right.$ being bigger than $1 q^{2}$ ), which end up positioned in a similar horizontal plane relative to each other (Fig. 2j-l). This cleavage pattern of the 1q micromeres generates an incipient blastocoel (Fig. 2l). Between 3 and 4 hpf, the fifth, dextral cleavage forms the third quartet of micromeres (3q) and a 32-cell stage embryo (Fig. 2m, n). Five hours after fertilization, the last, sinistral round of cell divisions generates the fourth quartet of micromeres (4q) and the 4Q macromeres (Fig. 2o, p). This 64-cell stage embryo, or mature coeloblastula, has a prominent central blastocoel (Fig. 2p), with the larger vegetal blastomeres forming the gastral plate that will invaginate during gastrulation. Owenia fusiformis embryos thus undergo typical equal spiral cleavage, similar to O. collaris [17], and apparently without signs of asymmetry between equivalent blastomeres of each embryonic quadrant, until the transition between the 32-cell to the 64-cell stage, when one of the 3q micromeres starts dividing first (Fig. 2o).

\section{Gastrulation}

Gastrulation begins around 5.5-6 hpf via the invagination of the vegetal gastral plate (Fig. 3a), with the $5 \mathrm{Q}$ macromeres becoming apically constricted at the vegetal 

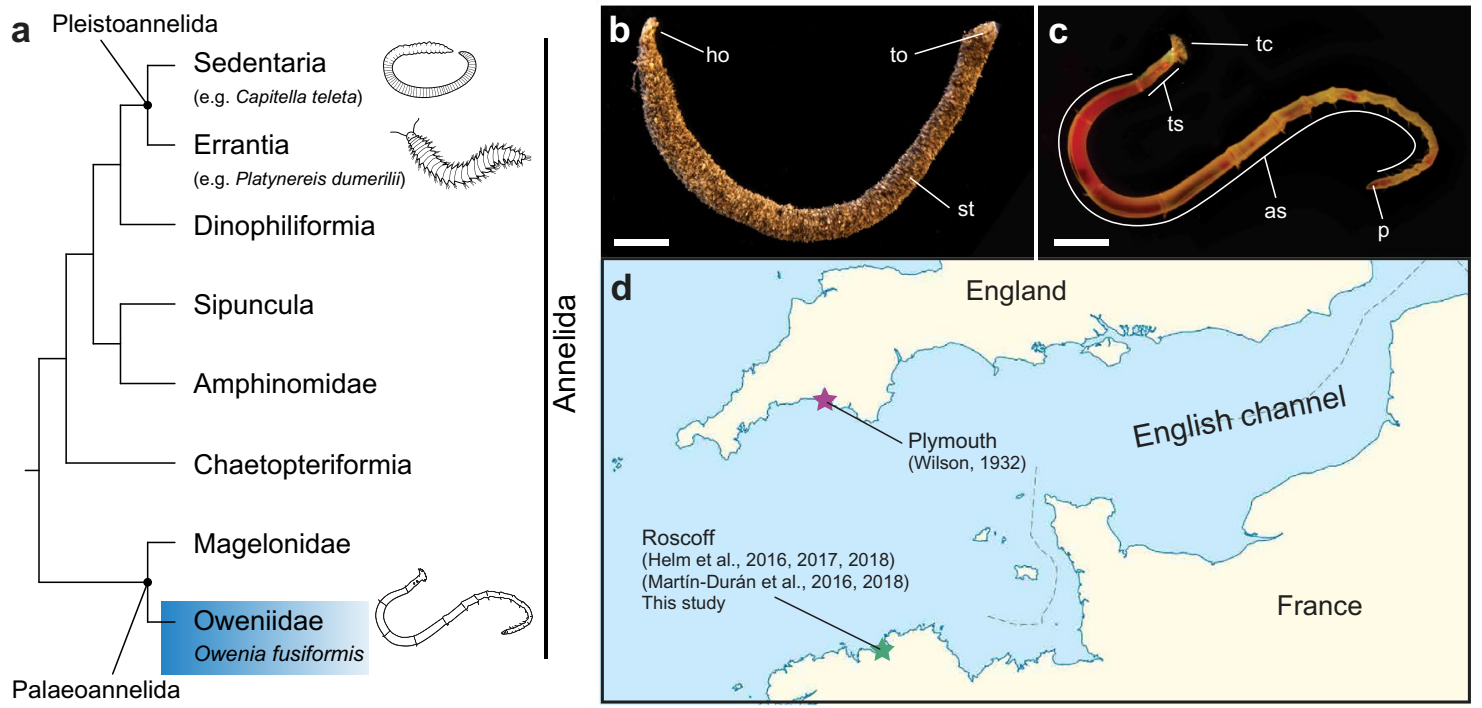

e
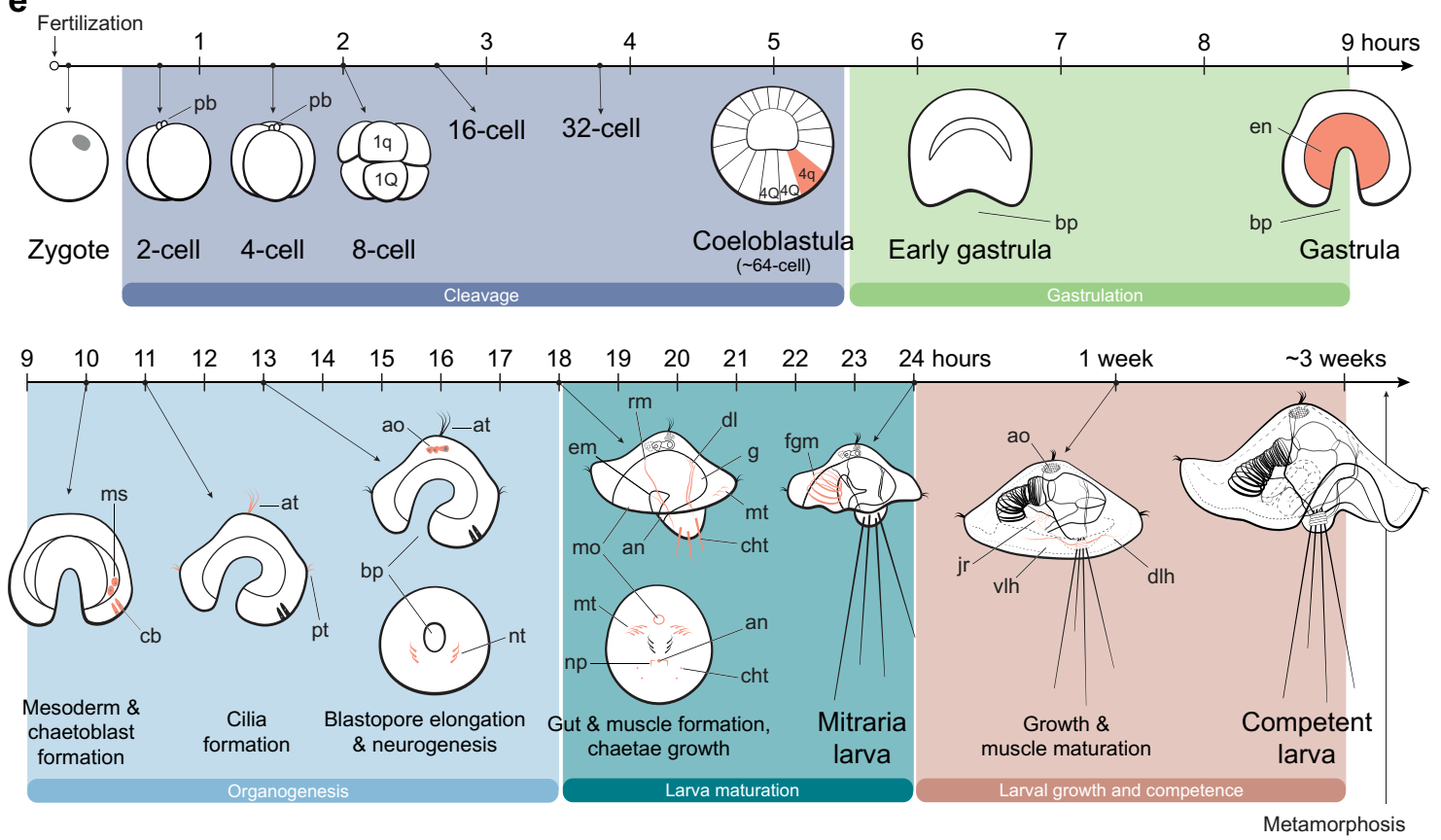

Fig. 1 Owenia fusiformis, phylogenetic position, sampling location, and embryonic development. a O. fusiformis (blue box) is a member of Palaeoannelida, the sister clade to all remaining annelids. Annelid phylogeny according to [1 1]; b, c as adult, 0 . fusiformis dwells inside a self-built sand tube. The adult body is divided into a head with tentacles, three thoracic segments, abdominal segments and a pygidium (c); d embryological studies on $\mathrm{O}$. fusiformis have focused on specimens collected from the English Channel, with the most recent ones studying a population near the Marine Biological Station of Roscoff, France. e Time course of developmental from oocyte to late mitraria larvae. Top row: Owenia fusiformis undergoes stereotypical equal spiral cleavage, formation of a coeloblastula and gastrulation by invagination. Bottom row: organogenesis starts with the formation of the mesodermal precursors and chaetoblasts, followed by the apical tuft and prototroch. By 13 hpf the blastopore elongates and a neurotroch forms posterior to the blastopore. Myogenesis starts when different larval muscles extend from the chaetal sac to the apical organ and gut. As the larva continues to grow until competence, several other muscles form. Red in e marks the first appearance of the most relevant cells or tissues at that stage. an: anus; ao: apical organ; at: apical tuft; as: abdominal segments; at: apical tuft; bp: blastopore; cb: chaetoblasts; cht: chaetae; dl: dorsal levator muscles; dlh: dorsolateral hyposphere muscles; em: esophageal muscle; en: endomesoderm; fgm: foregut muscle; ho: head opening; jr: juvenile rudiment; mo: mouth; ms: mesentoblasts; mt: metatroch; np: nephridia; nt: neurotroch; p: pygidium; pb: polar bodies; pt: protrotroch; rm: retractor muscles; st: sand tube; tc: tentacles; to: tail opening; ts: thoracic segments; vlh: ventrolateral hyposphere muscles. Scale bar is $2 \mathrm{~cm}$ 


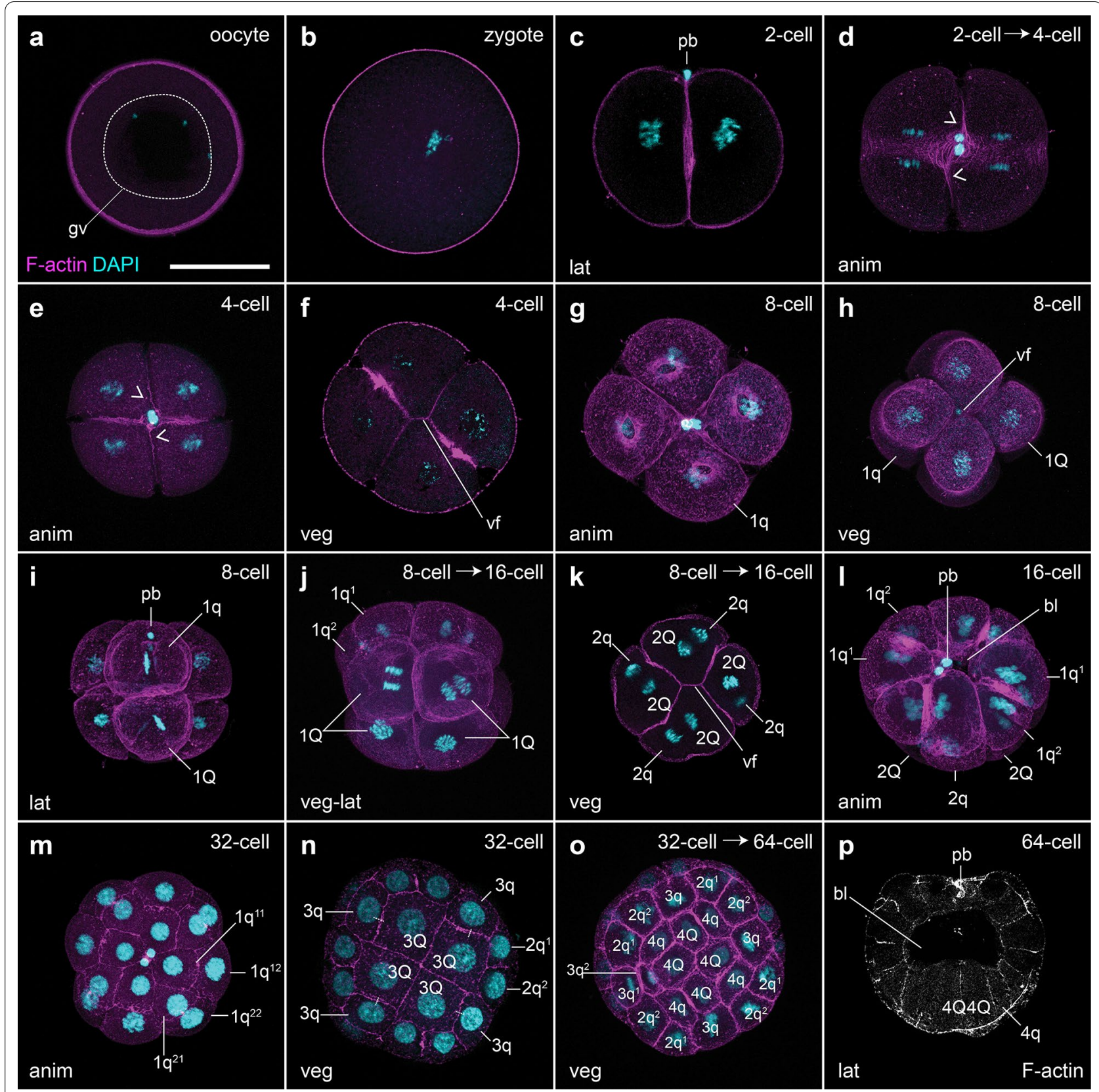

Fig. 2 Owenia fusiformis undergoes equal spiral cleavage. Confocal laser scanning microscopy (CLSM) images of early embryonic stages from a oocyte to $\mathbf{p}$ blastula stage (approx. 64-cell). a The oocyte activates naturally in sea water and after the germinal vesicle breaks down. b After fertilization, the embryo undergoes equal cleavage resulting in two and later four equal blastomeres (c-f). Open arrowheads in (d) and (e) points to the spiral deformation of the actin cytoskeleton in preparation for the dextral cleavage. $\mathbf{f}-\mathbf{k}$ The spiral cleavage initiates with the formation of four oblique micromeres $(1 \mathrm{q})$ that are larger than the macromeres $(1 \mathrm{Q})$. I-o Cleavage continues with the stereotypical alternation of the spindles back and forward from counterclockwise to clockwise to give rise to the second (2q) (I), third (3q) (m, n) and fourth (4q) quartet of micromeres (o, p), until the formatin of the coeloblastula (o). bl: blastocoel; gv: germinal vesicle; pb: polar bodies; vf: vegetal cross furrow. Scale bar is $50 \mu \mathrm{m}$

pole and leading the invaginating front, which eventually opens a blastopore by $6 \mathrm{hpf}$ (Fig. 3b). Seven hours after fertilization (7 hpf), the archenteron roof reaches the basal side of the animal ectoderm, making contact with at least one animal cell (Fig. 3c, inset). At this stage, the polar bodies appear internalized, between the archenteron roof and the animal ectoderm (Fig. 3d). Gastrulation completes by $9 \mathrm{hpf}$ (Fig. 3e-f). At this stage, which we refer to as the gastrula stage, the blastocoel is nearly completely obliterated, the archenteron cavity is fully 


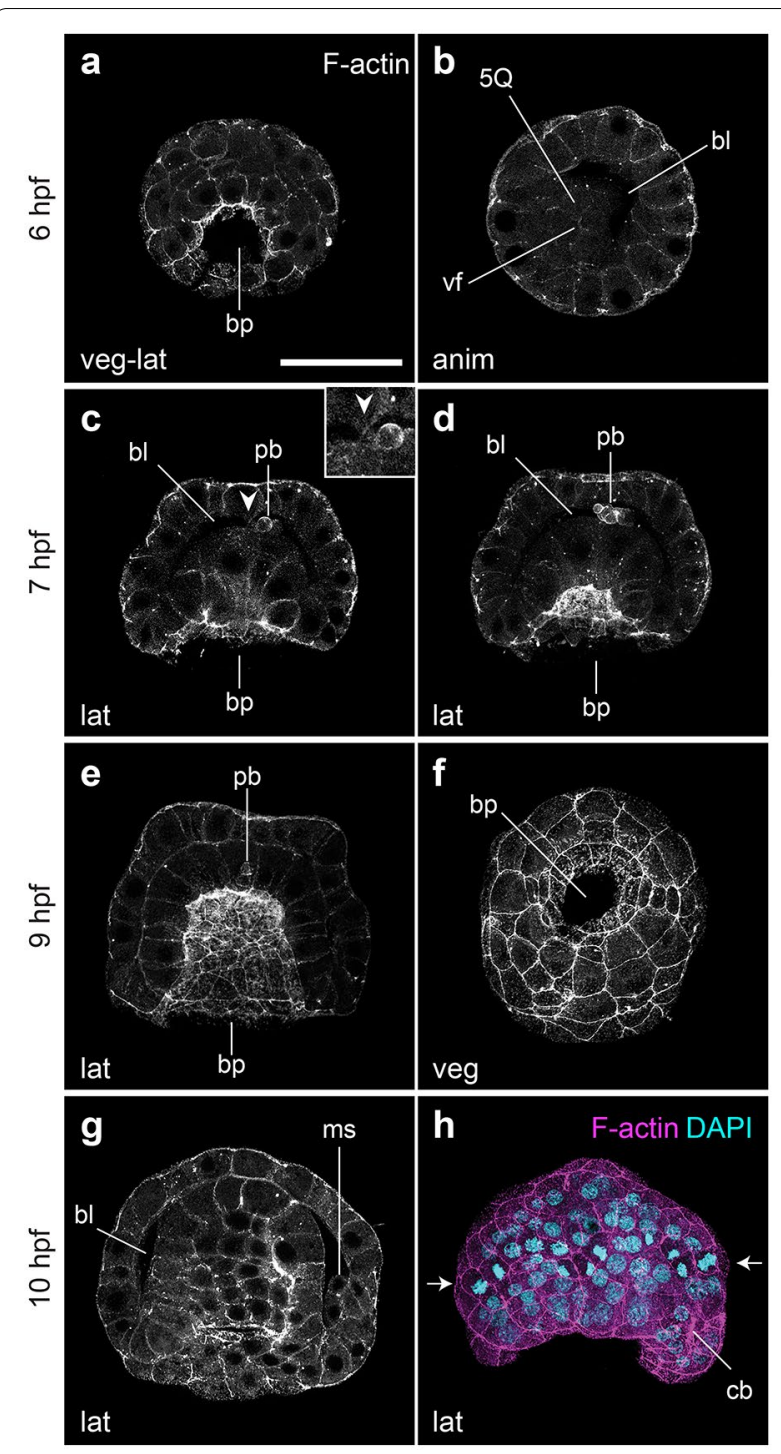

Fig. 3 Gastrulation via invagination in O. fusiformis. CLSM images of early embryonic stages from a 6 hpf (beginning of gastrulation) to $\mathbf{h} 10 \mathrm{hpf}$ (post gastrulation). a At $6 \mathrm{hpf}$ the gastral plate starts invaginating with the $5 \mathrm{Q}$ macromeres at the front of the archenteron roof (b). c By $7 \mathrm{hpf}$ the archenteron roof connects with the animal ectoderm (closed arrowhead) (inset), and the polar bodies have internalized into the blastocoel (c, d). e Gastrulation ends by 9 hpf, in which the two germinal layers: endoderm and ectoderm are formed; while the mesoderm precursors and chaetoblasts form at the dorso-posterior end of the embryo $(\mathbf{g}, \mathbf{h})$. Arrows in $(\mathbf{h})$ show the row of presumptive prototrochal cells dividing. bl: blastocoel; bp: blastopore; cb: chaetoblast; gv: germinal vesicle; ms: mesodermal precursor cells; pb: polar bodies; vf: vegetal cross furrow. Scale bar is $50 \mu \mathrm{m}$

formed, and the blastoporal opening and its rim occupy the entire vegetal pole. The polar bodies become internalized within one or two cells of the archenteron roof at this stage (Fig. 3e). At $10 \mathrm{hpf}$, two mesodermal precursor cells are visible in the blastocoel (Fig. 3g) and there is a band of dividing ectodermal cells located slightly vegetally to the equator (Fig. 3h). We interpret this row of cells as the presumptive prototroch, identified as the $1 \mathrm{q}^{2222}$ lineage in $O$. collaris [17]. In addition, at least two chaetoblasts appear on the same side of the vegetal pole as the mesodermal precursors (Fig. 3h). Because the chaetal sac will form on the dorso-posterior part of the embryo [14, 16-18], we deem the region of the gastrula where these chaetoblasts appear as the posterior end. Therefore, its appearance is the first evident morphological landmark revealing the anterior-posterior and dorsal-ventral axes of the embryo and marks the beginning of the axial elongation and organogenesis in the embryos of $O$. fusiformis.

\section{Organogenesis and development of the early mitraria larva}

The first external signs of organogenesis become evident at $11 \mathrm{hpf}$, when the prototroch, the largest ciliary band and main locomotive structure of the mitraria larva, becomes apparent at a comparable subequatorial ectodermal region with actively dividing cells at $10 \mathrm{hpf}$ (Fig. 3h). Although the prototrochal cells are not yet fully ciliated at $11 \mathrm{hpf}$, they define two large embryonic regions, namely the episphere on the former animal region and the hyposphere on the original vegetal pole. At this stage in the episphere, the first cilia differentiate at the apical tuft (Fig. $4 \mathrm{a}-\mathrm{c}$ ), as well as seven large cells of unknown function, named refringent globules by Wilson [16]. In the hyposphere, the dorso-posterior chaetal sac starts to form at $11 \mathrm{hpf}$, bearing four chaetoblasts, and the blastoporal opening narrows and elongates along the anterior-posterior axis (Fig. 4a). At $13 \mathrm{hpf}$, cells in the mid-posterior and lateral sides of the blastoporal rim start constricting, closing the blastoporal opening (Fig. 4d, e). Four pairs of ciliated cells are now present ventrally, slightly posterior to the closing edge of the blastoporal rim. Due to their bilateral symmetry and their position parallel to the anterior-posterior axis, we deem these cilia as a short and likely transient neurotroch (Fig. 4d, e). At this early stage, there is proliferation in most regions of the larval body, as we observe DNA replication (EdU signal) and mitotic activity (phosphoHistone $\mathrm{H} 3$ signal) especially in the hyposphere and the developing gut, but also in the apical organ and the ciliary bands (Fig. 5a, b).

By $18 \mathrm{hpf}$, the anterior blastoporal opening has formed the mouth [18], which is clearly separated from the anus by two or three rows of cells (Fig. 4f) (see also Fig. 2 in Wilson [16]), defining a short ventral side in the embryo. At this stage, the digestive tract is divided into foregut, midgut and hindgut, with the neurotroch cells positioned 
between the mouth and the anus. It is at this stage that a new group of scattered ciliated cells starts to emerge in the hyposphere, where the four chaetae now protrude from the chaetal sac (Figs. 5, 6). Associated with the enlargement of the prototroch and the appearance of more ciliated cells in the hyposphere, we observe increased proliferation in these areas (Fig. 5). In other trochophore larvae, designated cells called the trochoblasts become arrested and enlarged to form the multiciliated cells of the prototroch [23-25]. However, the mitraria larva has monociliated cells that are able to keep dividing and replacing lost cells within the ciliary bands [17, 26] (Fig. 5). This 18 hpf stage also reveals the first signs of myogenesis, with the appearance of the retractor muscles plus the dorsal levator muscles and esophageal muscles that connect the chaetal sacs to the apical side of the animal and to the esophagus, respectively (Fig. 4g). In addition, two tubulin ${ }^{+}$nephridia are flanking the anus (Fig. 4e). The increased ciliation at $18 \mathrm{hpf}$ facilitates the swimming behavior of the larva, which starts spinning at the bottom of the culture bowls.

From 22 to $27 \mathrm{hpf}$, the embryo matures into a mitraria larva. The circular muscles surrounding the foregut appear at $22 \mathrm{hpf}$ (Fig. $4 \mathrm{~h}-\mathrm{i})$. The initially sparse ciliated cells in the hyposphere are now more numerous and expand to cover most of this larval region as a secondary ciliary band, except the chaetal sac (Fig. 4h). Following Wilson [16] and Emlet and Strathmann [27], we herein refer to this ciliary band as the mitraria metatroch. As the prototroch matures, the mitraria also starts swimming in the water column and can already feed by $22 \mathrm{hpf}$. After $27 \mathrm{hpf}$, the mitraria larva is slightly larger, more ciliated (Fig. 4 j, k) and have longer and more robust chaetae (Fig. 6).

\section{Nervous system development in the early mitraria larva}

Previous neuroanatomical studies revealed a nervous system in the early mitraria larva consisting of one or two FMRFamide immunoreactive cells in the apical organ and possibly a lateral FMRFamide ${ }^{+}$axon $[14,15]$. However, most other annelid trochophore-like larvae display more complex nervous systems at the moment of hatching [28-30], thus suggesting that the early mitraria larva emerges with a rudimentary nervous system that matures as the larva grows. To test this scenario, we identified and analyzed the embryonic expression of the panneural marker gene elav1 [31-35] and the mature neuron marker synaptotagmin-1 (syt1) [32, 34, 36-40] (Fig. 6). The earliest stage showing expression of elav1 and syt 1 is $13 \mathrm{hpf}$, when elav $1^{+}$and $s y t 1^{+}$cells, which we consider neurons, locate around the forming apical tuft, conforming a V-shaped apical organ composed of one large cell in the center and two smaller lateral neurons (Fig. 6c-f, and insets within). As part of this incipient apical organ, there are two acetylated tubulin ${ }^{+}$flask-shaped monociliated cells (Figs. 4c, e, 7a). In addition, there are three anterior and four posterior neurons by the prototroch expressing elav 1 and syt 1 weakly (Fig. $6 \mathrm{c}-\mathrm{f}$ ). These seven neurons are apparently associated with the seven refringent globules. At this stage, none of the elav1 $1^{+}$and $s y t 1^{+}$ cells are immunoreactive against FMRFamide (Fig. 6a) and serotonin (Fig. 7h). Instead, the refringent globules are positive against FMRFamide and serotonin (yellow arrowheads, Figs. $6 \mathrm{a}, 7 \mathrm{f}-\mathrm{h}$ ), but considering they do not express elav1 or syt1, it is uncertain whether or not these cells are of neural or neurosecretory nature, or whether this is non-specific signal. By $18 \mathrm{hpf}$, more elav1 ${ }^{+}$and syt $1^{+}$cells appear in the circumesophageal connectives, the ventral tissue where the juvenile rudiment will form, and in a domain anterior to the foregut (Fig. 6i-l). At least two tubulin ${ }^{+}$cells make the loop of cilia that extrudes out of the larva in the apical tuft (Figs. 4g, 7b, e). These cells are in close vicinity to the retractor muscles and the two lateral axons that run from the apical organ towards the ventral side. This general pattern of the nervous system observed at $18 \mathrm{hpf}$ remains in the early mitraria larva, where neurons in the apical organ and in the seven neuronal cells of the prototroch become immunoreactive against FMRFamide, forming a prototrochal ring (Figs. $6 \mathrm{~m}-\mathrm{r}$, 7f, g). However, the expression of elav1 decays in the $27 \mathrm{hpf}$ mitraria, only remaining in a few cells of the apical organ and in the area where the juvenile rudiment will form (Fig. $6 u-x$ ). Altogether, our data demonstrate that neurogenesis starts earlier than

\footnotetext{
(See figure on next page.)

Fig. 4 Early mitraria larvae and the beginning of organogenesis. CLSM images of early larval stages from a $11 \mathrm{hpf}$ to $\mathbf{k} 27 \mathrm{hpf}$. Images on the left column are ventral views with anterior facing up, while those on the right are lateral views with anterior facing left, except for (b) which is an apical view. a-c Ciliogenesis starts at $11 \mathrm{hpf}$ with the formation of the apical tuft and the prototroch dividing the embryo into an apical episphere and a vegetal hyposphere. $\mathbf{d}$, e A short neurotroch then forms on the posterior side of the blastopore by $13 \mathrm{hpf}$. By this stage the blastopore elongates to form the presumptive mouth, but still remains open. $\mathbf{f}, \mathbf{g}$ By $18 \mathrm{hpf}$, the early mitraria now has a secondary ciliary band, the metatroch, in addition to a complete gut, larval muscles and chaetae. $\mathbf{h}-\mathbf{k}$ Soon after, the larva grows and expands the metatroch throughout the hyposphere, while more muscle develops, including circular muscles around the foregut. an: anus; at: apical tuft; bl: blastocoel; bp: blastopore; cb: chaetoblast; cht: chaetae; cs: chaetal sac; dl: dorsal levator; em: esophageal muscle; fg: foregut; fgm: foregut circular muscle; hg: hindgut; mg: midgut; mo: mouth; mt: metatroch; np: nephridia; nt: neurotroch; pt: prototroch; rg: refringent globules; rm: retractor muscle; tm: membrane between chaetal sac and blastocoel. Scale bar is $50 \mu \mathrm{m}$
} 


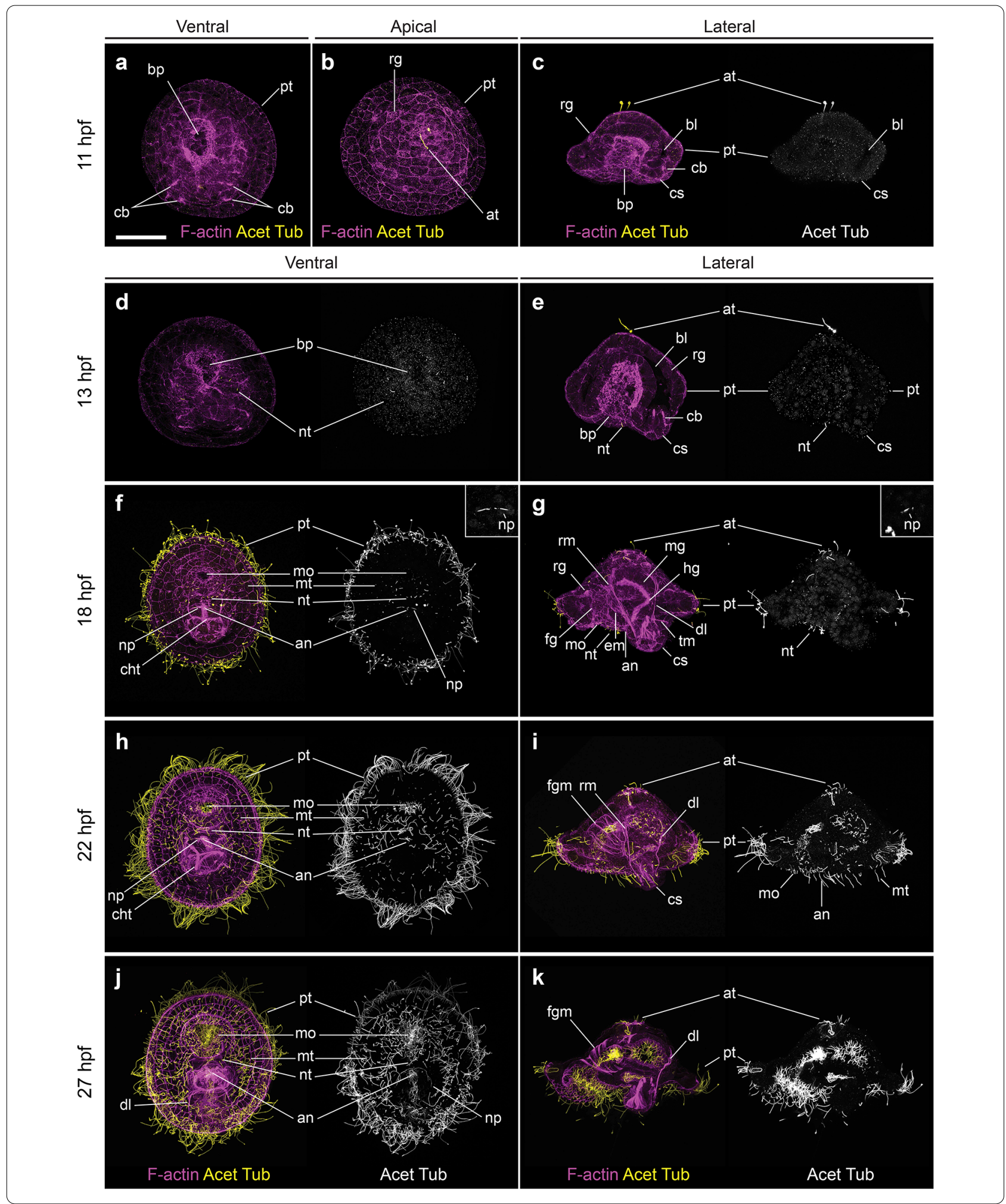

previously recognized in O. fusiformis, initiating on the apical side and extending posteriorly in conjunction with other morphogenetic events.

\section{Growth and competence of the mitraria larva}

The $27 \mathrm{hpf}$ complete mitraria is an active planktotrophic stage that acquires competence and undergoes 


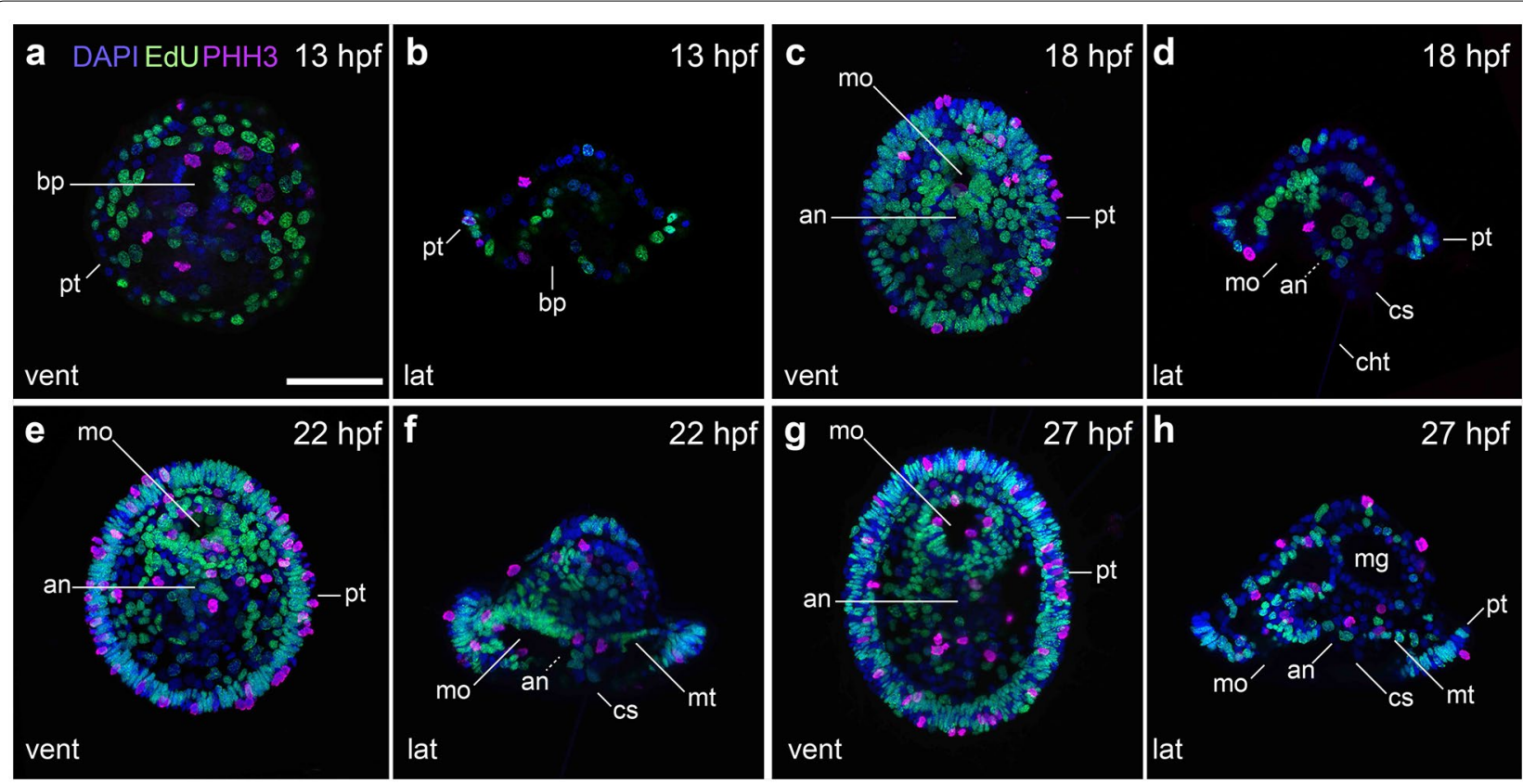

Fig. 5 Cell proliferation during early mitraria. CLSM images of EdU and phospho-Histone 3 (PHH3) labeling on early mitraria larvae from a 13 hpf to $\mathbf{h} 27 \mathrm{hpf} . \mathbf{a}, \mathbf{c}, \mathbf{e}, \mathbf{g}$ Are ventral views with anterior facing up, while $\mathbf{b}, \mathbf{d}, \mathbf{f}, \mathbf{h}$ are lateral views with anterior facing left. Cell proliferation is widespread throughout the body, overlapping with cells that are mitotically active in the ciliary bands and the developing gut. an: anus; bp: blastopore; cht: chaetae; cs: chaetal sac; mg: midgut; mo: mouth; mt: metatroch; pt: prototroch. Scale bar is $50 \mu \mathrm{m}$

a dramatic metamorphosis after about 3 weeks at $15^{\circ} \mathrm{C}$. One week post-fertilization (wpf), the mitraria feeds and grows considerably in size, partly through cell division, but likely also through cell growth and cell shape changes (Fig. 8a, b). The epithelial cells of both the episphere and hyposphere become large and very thin $[14,16]$, often displaying a variety of nuclear shapes and sizes. Related to this growth, the prototroch bends (Figs. 8a, 9a, e) and the metatrochal cells rearrange into a single row, leaving a cleared narrow epidermal zone in the hyposphere. In both the prototroch and the metatroch of the mitraria, we found evidence of cell proliferation (Fig. 9a, e). Two clearly distinct ciliary bands thus form, leaving a food groove in between (Figs. 8a, b, 9a) $[16,17,27]$. Internally, the apical organ becomes more elaborated and new pairs of muscles appear. In addition to the esophageal, the dorsal levator and retractor muscles (Fig. 8a, b), the chaetal sac connects to the hyposphere through the ventrolateral hyposphere muscles and the dorsolateral hyposphere muscles (Fig. 8a, b). The muscles surrounding the chaetal sac also become more robust (Fig. $8 \mathrm{~b}$ ). Already at this stage the juvenile rudiment starts to form, initially as an ectodermal invagination between the mouth and the anus, with the latter eventually becoming incorporated into the newly forming trunk (Figs. 8a, 9a, e).
During the following 2 weeks, the bends of the prototroch exaggerate, forming anterior and posterior lappets (Figs. $8 \mathrm{c}-\mathrm{h}, 9 \mathrm{~b}-\mathrm{d}, \mathrm{f}-\mathrm{g}$ ), a pair of eyes appear near the apical tuft $[14,16]$ and the nephridia enlarge on both left and right sides of the hyposphere (Fig. 8c, e, g) [16, $41,42]$. As previously described [14, 43], the nervous system also becomes more complex, with new nerves (peripheral nerves 1-3 and dorsal nerve) connecting the apical organ to various regions of the prototroch, and the circumesophageal connectives to the juvenile nerve cord (Fig. 8c-h). At these late mitraria stages, expression of elav1 is only found in the developing nerve cord of the juvenile rudiment (Fig. 10d-f), suggesting that this tissue is the active site of neurogenesis. Mature FMRFamide ${ }^{+}$ neurons also expressing syt1 compose the rest of the larval nervous system including the apical organ, which will be the brain of the juvenile $[14,16]$, and the juvenile rudiment (Fig. 10a-c, g-i). An FMRFamide ${ }^{+}$nerve innervates the chaetal sac (Fig. 10c), which suggests this neuropeptide might control chaetal movements, as in a brachiopod larva [44].

Larval competence is acquired at about $3 \mathrm{wpf}$ at $15^{\circ} \mathrm{C}$, when the juvenile rudiment is well-developed and protrudes out of the hyposphere, immediately anterior to the chaetal sac. During maturation, the juvenile rudiment grows in a posterior to anterior direction $[16,17]$ with the trunk cells extending dorsally from the ventral 


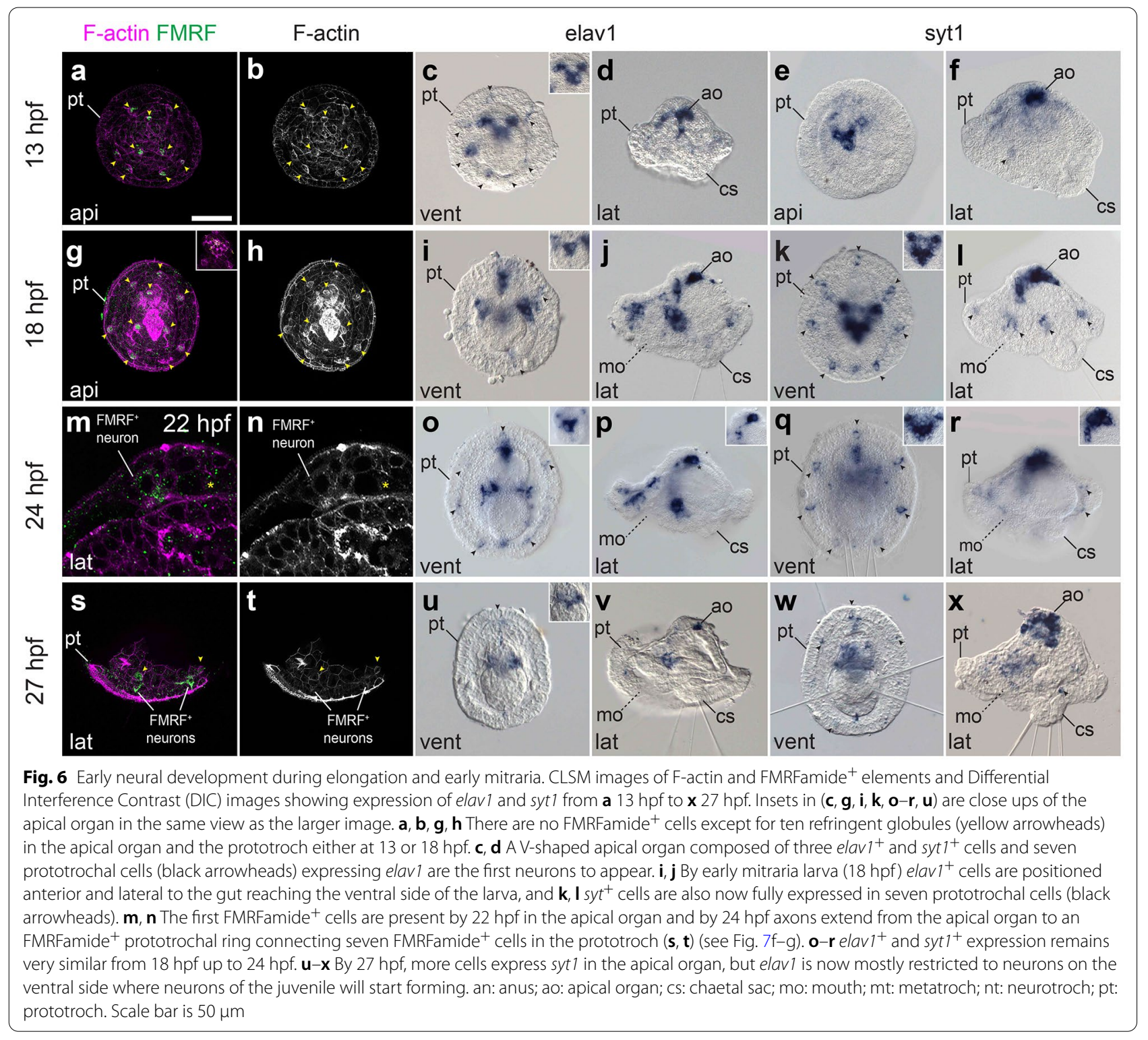

side to wrap the gut and incorporate the larval digestive system into the developing juvenile trunk. Interestingly, the EdU and phospho-Histone H3 signal suggests there is a presumptive proliferation zone at the most posterior part of the trunk (magenta cells in Fig. 9 $\mathrm{e}^{\prime}-\mathrm{g}^{\prime}$ ), which could represent a posterior growth zone, like in many other annelids [45-48]. Metamorphosis is often triggered by adding a pinch of mud to the bowl with competent mitraria larvae. During this drastic event, the apical organ fuses with the developing ventral nerve cord and becomes the juvenile brain $[14,16]$, the larval gut is incorporated into the juvenile, which consumes the rest of the larval tissue while shedding the chaetal sac $[16,17]$. Soon after metamorphosis, the juvenile will start forming the sand tube where the adult dwells (Fig. 1b).

\section{Discussion}

Our data provide a detailed analysis of the early development and organogenesis of $O$. fusiformis, defining a staging system and a set of morphological landmarks (Figs. 1e, 10j) that will serve as reference for future developmental and evolutionary studies in this species, and annelids and spiralians generally.

\section{The early spiral cleavage and gastrulation of Owenia}

Previous descriptions of the early embryonic stages in Oweniids were only available for O. collaris [17]. Our 

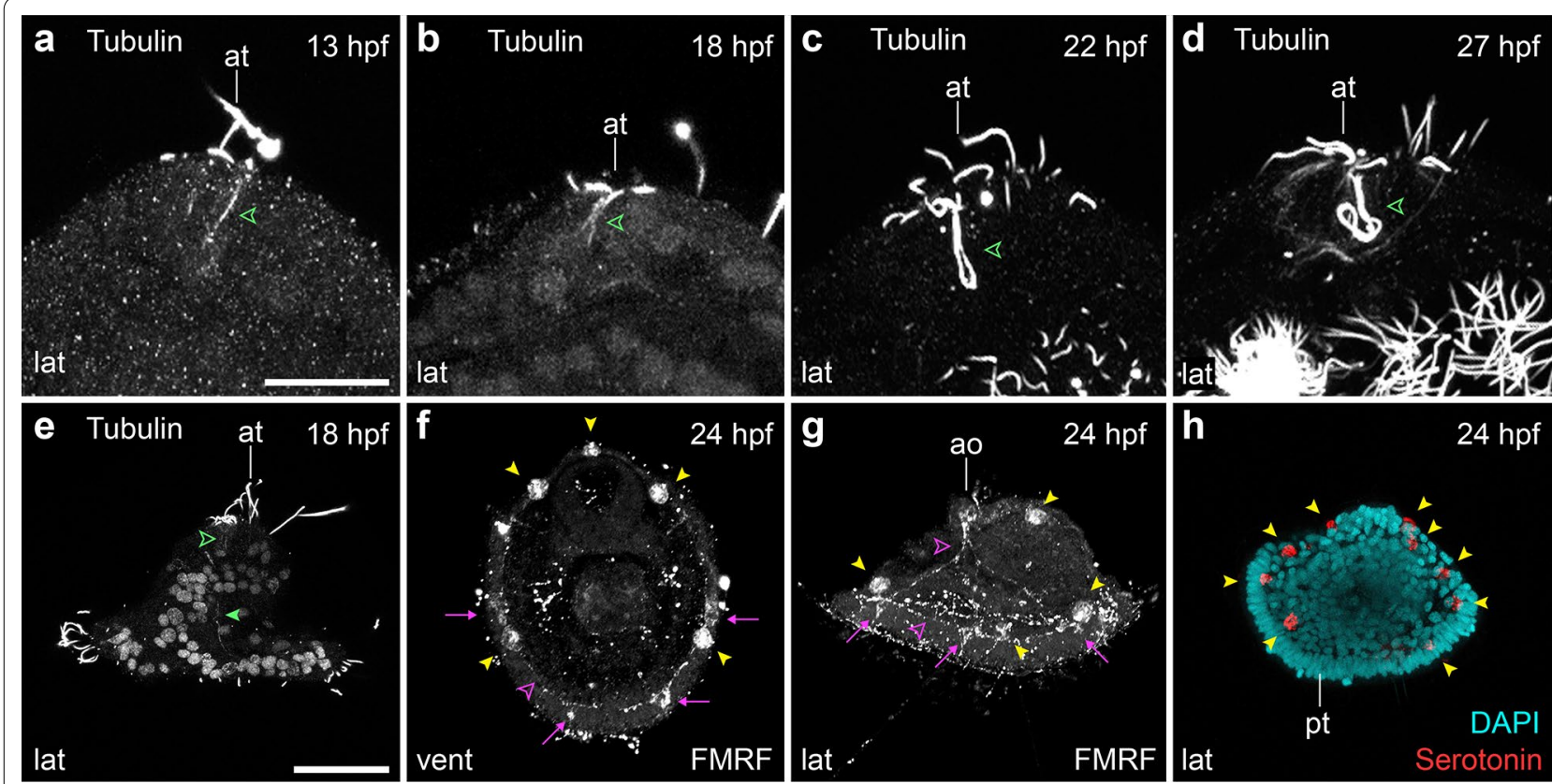

Fig. 7 Tubulin $^{+}$and FMRFamide ${ }^{+}$elements during neurogenesis. CLSM images of early larval stages from a $13 \mathrm{hpf}$ to $\mathbf{h} 24 \mathrm{hpf}$. a-d Close ups of the apical tuft innervation into the apical organ (green open arrowhead). e By $18 \mathrm{hpf}$ an axon connects the apical organ with the prototroch (green closed arrowhead). f, $\mathbf{g}$ The apical organ connects with the neurons along the prototroch (magenta arrows), which start to be FMRFamide immunoreactive by 22-24 hpf (see Fig. $6 \mathrm{~m}, \mathrm{n}$ ). These neurons eventually form an FMRFamide ${ }^{+}$prototrochal ring (magenta arrowheads) which connects with the apical organ via an FMRFamide ${ }^{+}$axon (magenta arrowheads). $\mathbf{g}$, $\mathbf{h}$ The refringent globules that develop from 11 hpf, by 24 hpf are both FMRFamide ${ }^{+}$and serotonin ${ }^{+}$. ao: apical organ; at: apical tuft; pt: prototroch. Scale is $25 \mu \mathrm{m}$ in (a-d). Scale bar in (e-h) is $50 \mu \mathrm{m}$

study demonstrates that spiral cleavage stages are practically identical between $O$. fusiformis and O. collaris, aside from timing differences that are likely due to different culture temperatures $\left(12{ }^{\circ} \mathrm{C}\right.$ in O. collaris versus $19{ }^{\circ} \mathrm{C}$ in O. fusiformis). Both Owenia species undergo dextral spiral cleavage, and this chirality is already observed as early as in the second cleavage in O. fusiformis. Remarkably, the spiral deformation of the actin cytoskeleton in the 2-cell stage embryo has also been described in some mollusk species $[49,50]$, and might thus indicate the presence of common early cellular mechanisms underlying embryonic chirality in spiralians. Later on, Owenia embryos follow what appears to be a general, probably ancestral pattern for equal spiral cleaving annelids, which includes a symmetric pattern of cell divisions between embryonic quadrants, the formation of a coeloblastula, and gastrulation via invagination [51-57]. In some serpulids [54, 58, 59], one hesionid [59] and one echiuran [55], which are equal cleavers, the asymmetrical division of $2 \mathrm{~d}^{2}$ into a larger $2 \mathrm{~d}^{21}$ and smaller $2 \mathrm{~d}^{22}$ is a landmark of the D-quadrant. However, we did not observe this change in the pattern of cell divisions breaking the embryonic symmetry. Albeit one of the 3q micromeres divides first, we cannot pinpoint which of the four $3 q$ this might be.

\footnotetext{
(See figure on next page.)

Fig. 8 Late mitraria larvae and juvenile rudiment development. CLSM images of late larval stages from a 1 wpf to $\mathbf{h} 4$ wpf. a, c, e and $\mathbf{g}$ Are ventral views with anterior facing up, while $\mathbf{d}, \mathbf{f}$ and $\mathbf{h}$ are lateral views with anterior facing left. $\mathbf{b}$ Close ups of specimens at 1 wpf. $\mathbf{a}$ The mature larva continues to grow and develop more musculature to connect the chaetal sac to different parts of the episphere and the hyposphere. The prototroch starts making bends (open arrowheads), and the metatroch is cleared from the chaetal sac and the ventral area where the juvenile rudiment is developing. $\mathbf{b}$ Both the hyposphere and episphere epithelial cells enlarge, the apical organ becomes more prominent and is full of microvilli, and the chaetal sac muscles become more robust. $\mathbf{c}-\mathbf{h}$ The apical organ now is connected to the prototrochal ring via peripheral and dorsal nerves. Cyan arrowheads point to the retractor muscles. Yellow arrowheads point to esophageal and dorsal levator muscles. Red arrowheads point to branching muscle connecting the peripheral regions of the ventrolateral hyposhere and the dorsolateral hyposphere muscles. an: anus; ao: apical organ; at: apical tuft; cc: circumesophageal connectives; cs: chaetal sac; dl: dorsal levator; dn: dorsal nerve; fg: foregut; jr: juvenile rudiment; Ip: lappet; mg: midgut; mo: mouth; mt: metatroch; np: nephridia; nt: neurotroch; pn 1-pn3: peripheral nerves 1 to 3; pt: prototroch. Scale bar is 50 $\mu$ m. In $\mathbf{b}$ the scale bar is $25 \mu \mathrm{m}$
} 


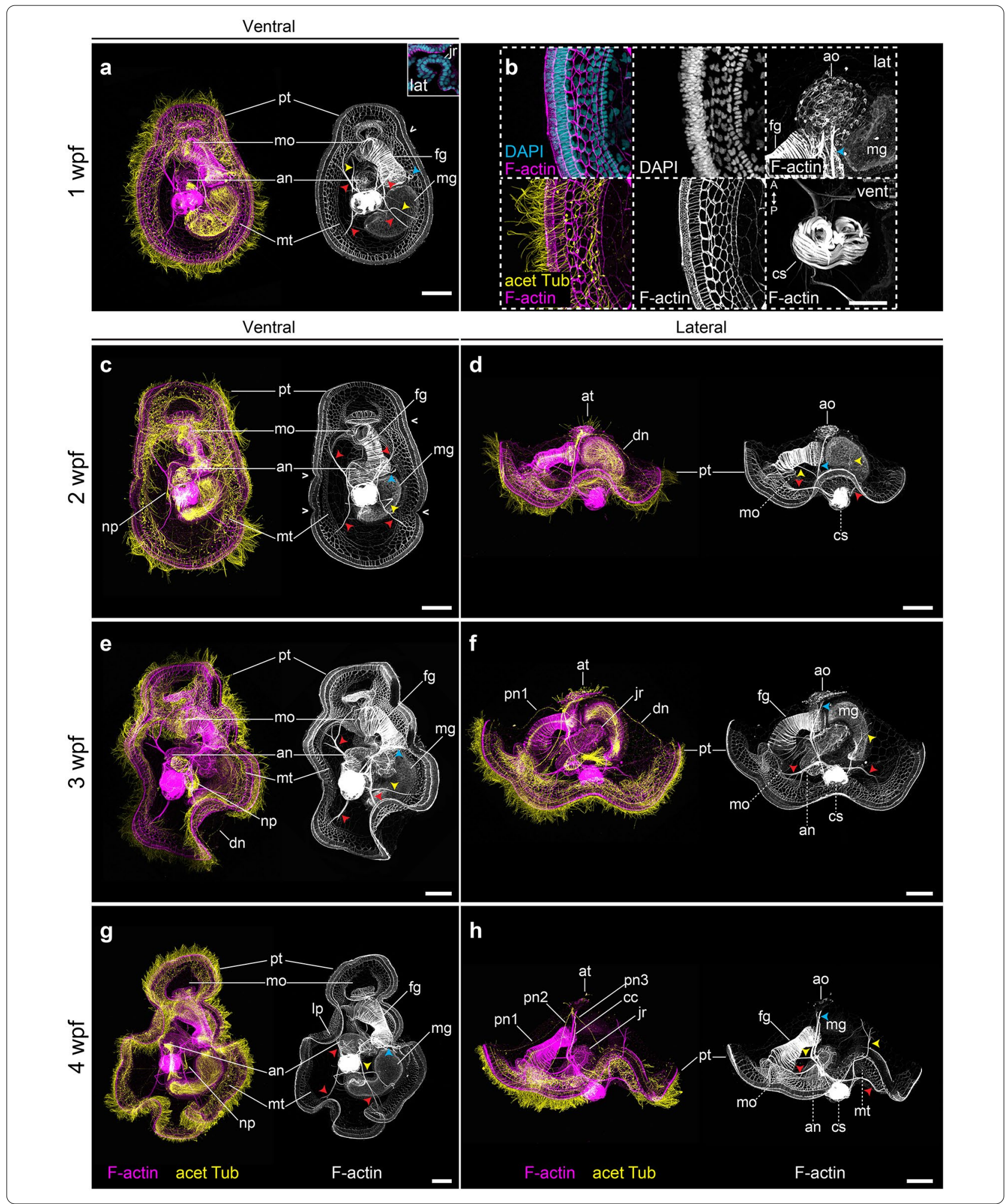

Therefore, elucidating the quadrant identity of each embryonic region in O. fusiformis would require combining cell positional information with potential molecular asymmetries observed in some equal cleaving annelids, such as the activation of the MAPK pathway in the presumptive $4 \mathrm{~d}$ cell [58]. 


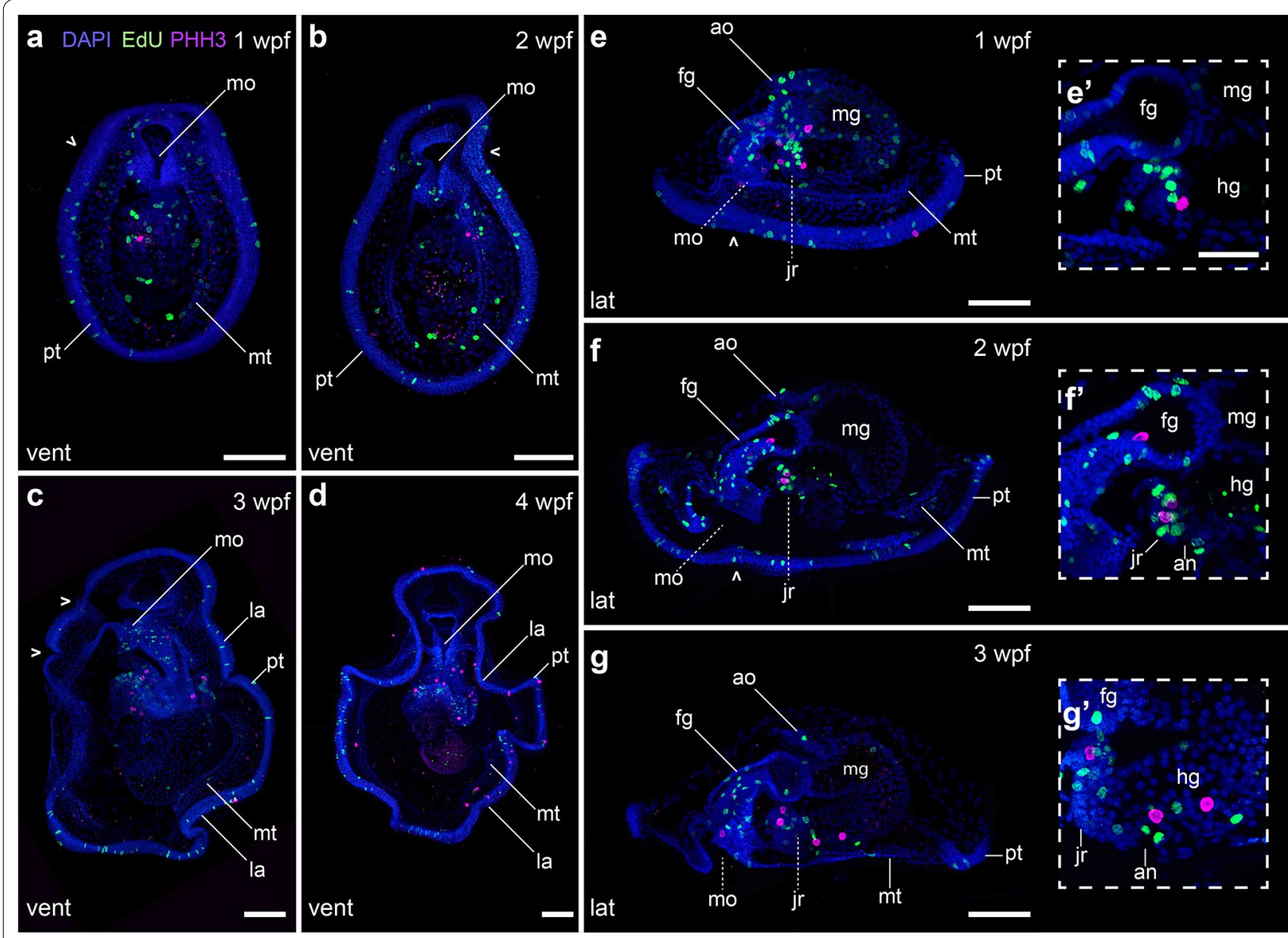

Fig. 9 Growth of the late mitraria larvae. CLSM images of EdU and phosphoHistone 3 (PHH3) labeling on mitraria larvae from a, e 1 wpf to $\mathbf{d} 4$ wpf. Images in $\mathbf{a}-\mathbf{d}$ are ventral views with anterior facing up, while those in $\mathbf{e}-\mathbf{g}$ are lateral views with anterior facing left. $\mathbf{e}^{\prime}-\mathbf{g}^{\prime}$ Are close-up sections of $(\mathbf{e}-\mathbf{g})$. a- $\mathbf{g}$ Proliferation in the late mitraria continues mostly in the ciliary bands, the gut and the developing juvenile rudiment. Open arrowheads point to the flexions of the ciliary band. $\mathbf{e}^{\prime}-\mathbf{g}^{\prime}$ The juvenile rudiment has proliferative cells and a terminal mitotic cell, in what it could represent a posterior growth zone. an: anus; ao: apical organ; bp: blastopore; cs: chaetal sac; fg: foregut; hg: hindgut; jr: juvenile rudiment; la: lappet; mg: midgut; mo: mouth; mt: metatroch; nt: neurotroch; pt: prototroch. Scale bar is $50 \mu \mathrm{m}$. In $\mathbf{e}^{\prime}-\mathbf{g}^{\prime}$ the scale bar is $25 \mu \mathrm{m}$

A remarkable trait of Owenia early embryogenesis is the larger size of the 1q micromeres compared to the $1 \mathrm{Q}$ macromeres, and subsequently of the $1 \mathrm{q}^{1}$ quartet versus their $1 \mathrm{q}^{2}$ sisters (Fig. 1e). In the majority of annelids and spiralians, the $1 \mathrm{Q}$ macromeres acquire a larger size and a larger allocation of cytoplasm and yolk, because the entire trunk ectoderm, mesoderm and endoderm will form from these lineages [3]. However, in annelids with small eggs like Owenia, egg size has been correlated with the allocation of cytoplasm to the micromeres and with larval feeding mode [60]. This reverse ratio between micromere and macromeres is present in another group of annelids, the sipunculans [20,61], where the larger micromere size is thought to contribute to the enlarged amount of apical/anterior ectoderm in the trochophorelike larva of this group, which has big prototrochal cells [20]. Outside Annelida, enlarged 1q micromeres are common in nemertine embryos, where these first micromere quartet forms the predominant anterior/apical region of their swimming larvae [22, 62]. Therefore, the presence of relatively larger size of $1 \mathrm{q}$ micromeres in O. fusiformis could explain the development of a larger episphere in the mitraria larva, as well as the expanded apical/anterior ectoderm in other spiralian larvae.

\section{Morphogenesis and larval development}

Our detailed microscopical study of the mitraria development and growth expands on the descriptions done by Wilson [16] on specimens collected on the British side of the English Channel (Plymouth, UK) (Fig. 1d). We define the onset of key morphogenetic events, such as chaetogenesis (10 hpf), ciliogenesis (11 hpf), myogenesis and gut formation (in both cases between 13 and $18 \mathrm{hpf}$ ) (Fig. 1e). Certain trends become evident when comparing 


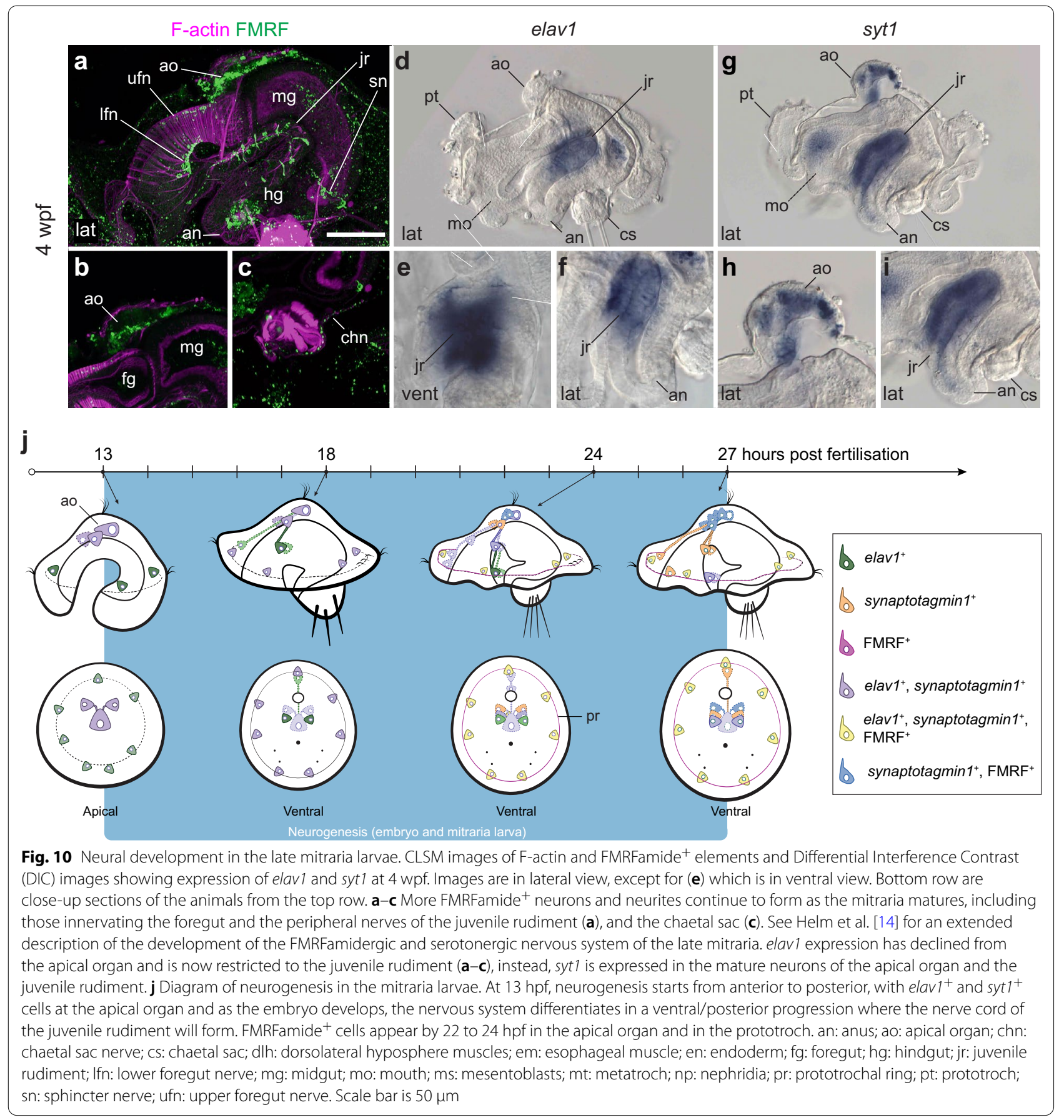

annelids which have a feeding larva like Owenia to those which have a non-feeding lecithotrophic larva (i.e., supplied with nutritional yolk by the mother). Feeding larvae tend to form a functional gut earlier [48, 63-66], as well as chaetae and muscle associated with chaetae for defense against predators $[48,64,65]$. On the other hand, non-feeding larvae tend to accelerate the development of juvenile structures (e.g., a definitive brain and muscles) that will be carry over after metamorphosis $[36,48,63$, 64, 66, 67]. However, interspecific comparisons of these events are often challenging, because of technical variability in rearing methods and due to species-specific differences in the timing of morphogenesis.

Annelid trochophore larvae have multiple and distinct ciliary structures, including an apical tuft, a prototroch, a neurotroch, a metatroch and/or a telotroch $[68,69]$. 
Our study demonstrates that the first cilia to appear in O. fusiformis are those in the apical tuft and the prototroch, followed by the neurotroch, and lastly the metatroch (Fig. 1e). Further cell-lineage studies will clarify the exact developmental origins of these ciliated bands and their homology to those of other annelid and spiralian larvae. As observed in other annelid studies with enough temporal resolution, the prototroch and apical tuft develop quicker, presumably providing the early larvae with a way to move and sense the environment [32, $65,70]$, while the metatroch differentiates soon after, in preparation for feeding. Unlike the definitive prototrochal cells of other annelid and spiralian larvae [26, 27, 71 ], ciliated cells in oweniids are monociliated [17, 72], and thus can continue dividing once differentiated and integrated in the ciliated band, as previously observed in O. collaris $[17,26]$ and our study shows for $O$. fusiformis (Figs. 5, 9). Indeed, the prototroch putatively arises from a row of equatorial cells that actively divide in the early post-gastrula (Fig. 3h), and continuous proliferation of cells in both the prototroch and the metatroch contribute to expand these bands and elaborate the feeding apparatus of the larva (Figs. 5, 9). This continuous growth and bending of the ciliary bands is similar to what is observed in other larvae with monociliated cells, such as those of deuterostome invertebrates [26], and help the mitraria larvae to improve with food collection and swimming efficiency [27].

Our study demonstrates a previously unrecognized number of cells in the nervous system of the early mitraria larva (Figs. 6 and 10j). The expression of neural genes revealed the presence of neurons in the apical organ as early as $13 \mathrm{hpf}$ (Fig. 6), soon after the appearance of the apical tuft at $11 \mathrm{hpf}$ (Fig. 4a-c). Likewise, we found neurons positioned on the apical margin of the prototroch, which are presumably sensorial, but might also be involved in controlling the ciliary beating of the prototrochal band and connecting this structure to the apical organ [14]. These early neurons do not initially display common neurotransmitters (e.g., serotonin and FMRFamide), but FMRFamide ${ }^{+}$cells appear in the apical organ soon after $22 \mathrm{hpf}$, significantly earlier than the 7 days post-fertilization previously reported [14]. While we grew the early larvae at a slightly warmer temperature than in previous works [14], disagreements in the time of appearance of neurons possibly relate to differences in the experimental protocols followed in each study. Nevertheless, neurogenesis (i.e., differentiation of the first neurons and neurites) progresses from anterior to posterior in O. fusiformis. In some members of Sedentaria (e.g., Spirobranchus lamarcki [65] and Malacoceros fuliginosus [32]) and Errantia (e.g., Platynereis dumerilii [73] and Phyllodoce maculata [74]), neurogenesis starts with a dual anterior and posterior differentiation of pioneer neurons, which has been proposed as the ancestral condition to Pleistoannelida or even Annelida as a whole [32]. However, our findings in O. fusiformis are in agreement with observations in sipunculans $[34,75,76]$ and dinophilids [39, 77], thus suggesting that an initial anterior/apical specification of neurons and pioneer neurons is common in groups outside Pleistoannelida. Interestingly, either condition is present haphazardly across members of Spiralia (Additional file 1: Table S1), suggesting that either the presence of two neurogenic centers was ancestral and got repeatedly lost in early annelid lineages and other spiralians, or the development of the nervous system from both anterior and posterior pioneer neurons evolved convergently multiple times in Annelida and Spiralia. A broader analysis of neural markers in multiple early annelid lineages and pleistoannelids will help to discriminate between these evolutionary scenarios.

\section{Conclusions}

Our study describes early cleavage, gastrulation and larval development in the palaeoannelid species $O$. fusiformis. This species exhibits a canonical equal spiral cleavage program, which as in other equal cleaving annelids, appears to be associated with the formation of a coeloblastula, gastrulation via invagination, and the development of a feeding larva [51-57]. Given the distribution of these characters across annelid and spiralian phylogeny, these could represent ancestral developmental traits for Annelida. Further studies in magelonids, the sister lineage to oweniids, will clarify whether all palaeoannelids exhibit similar developmental strategies. In addition, our study sets a timing for the onset of major morphogenetic and differentiation events during organogenesis, uncovering that neurogenesis starts soon after gastrulation, much earlier than previously recognized. Altogether, our study establishes a reference description and staging of the embryogenesis of O. fusiformis, an emergent research annelid species for cell, developmental, and evolutionary biology.

\section{Methods}

\section{Adult culture, spawning and in vitro fertilization}

Adults of O. fusiformis Delle Chiaje, 1844 (Fig. 1b, c) and mud were collected and shipped from the subtidal waters near Roscoff, France (Fig. 1d). The worms were acclimated inside aquaria with aerated artificial sea water (ASW) and mud at $15{ }^{\circ} \mathrm{C}$ for about 1 week after arrival. On the day of the artificial fertilization, a group of individuals were placed in a glass bowl with clean ASW, and later relaxed with $8 \% \mathrm{MgCl}_{2}$ for $10-12 \mathrm{~min}$ (Additional file 2: Fig. S1a, b). Juveniles and adults of $O$. fusiformis build tubes out of sand (Fig. 1b). Therefore, 
after relaxation each tube was opened manually, and then the animals were placed individually in a well of a 6-well plate containing $0.22-\mu \mathrm{m}$ filtered-ASW (FSW) (Additional file 2: Fig. S1c). The sex of each animal was determined by protruding a small opening of the coelomic cavity with fine forceps, allowing for either oocytes or sperm to be observed. There is a 50:50 ratio of males and females (Additional file 2: Fig S1e). All males were combined into a single bowl with enough water to keep them wet. On the other hand, groups of 4-5 females were placed into separate bowls (Additional file 2: Fig S1d). Females were dissected to release the oocytes inside the coelom. The oocytes were passed through a $150-\mu \mathrm{m}$ mesh to remove remaining pieces of female tissue and subsequently through a 70- $\mu \mathrm{m}$ mesh to filter small immature oocytes and coelomic content out. During adult dissection, both male and oocyte bowls were kept at $4{ }^{\circ} \mathrm{C}$ to prevent premature sperm and egg activation, respectively. Oocytes were then incubated at $19^{\circ} \mathrm{C}$ for $\sim 45 \mathrm{~min}$ to allow germinal vesicle breakdown and thus oocyte activation. Simultaneously, 4-5 males were placed in a glass bowl with a small volume of ASW and dissected to obtain sperm. Sperm activation was monitored by taken one drop of concentrated sperm and observing it under a $40 \times$ objective of a compound microscope. The remaining concentrated sperm was diluted into $50 \mathrm{ml}$ of FSW and kept at $19{ }^{\circ} \mathrm{C}$. Once the eggs were activated, $125 \mu \mathrm{l}$ of diluted sperm was pipetted into the glass bowls containing the oocytes. After $30 \mathrm{~min}$, the sperm was washed out with three rinses in FSW, and the embryos were cultured at $19{ }^{\circ} \mathrm{C}$ until they reach the desired developmental stage. Swimming mitraria emerged at approximately $24 \mathrm{~h}$ postfertilization, when they were transferred to plastic beakers containing $600 \mathrm{ml}$ of ASW and placed on a rocker at $30 \mathrm{rpm}$ in a controlled temperature room at $15^{\circ} \mathrm{C}$ (Additional file 2: Fig. S1f). Three times a week, we exchanged the ASW of the beakers and fed the larvae with $100 \mu \mathrm{l}$ of Reef Juice-Live Phytoplankton Blend (Reefphyto).

\section{Proliferation assays}

Embryos and larvae from 9 hpf to 4 wpf were incubated in $3 \mu \mathrm{M}$ 5-ethynyl-2'-deoxyuridine (EdU; ThermoFisher Scientific, cat\#: C10639) in FSW for 15-30 min. Specimens were then relaxed in $8 \% \mathrm{MgCl}_{2}$ for 10 min and fixed with $4 \%$ paraformaldehyde for $1 \mathrm{~h}$ at RT with constant rocking. EdU incorporation was visualized with a Click-iT EdU Alexa Fluor 594 (ThermoFisher Scientific, cat\#: C10639) following the manufacturer's instructions. Immunostaining (below) was performed after the ClickiT reaction.

\section{Immunohistochemistry}

Antibody staining was carried out as previously described $[14,18]$. Briefly, fixed samples were washed quickly with PBS, permeabilized with washes of $\mathrm{PBS}+0.1 \%$ Triton $\mathrm{X}-100+1 \%$ bovine serum albumin $(\mathrm{PTx}+\mathrm{BSA})$ over $1 \mathrm{~h}$, and blocked in PTx $+0.5 \%$ normal goat serum (NGS) for $1 \mathrm{~h}$. Samples were incubated in primary antibodies diluted in NGS overnight at $4{ }^{\circ} \mathrm{C}$ while rocking, and subsequently washed four times in 30-min intervals with PTx + BSA while rocking. Secondary antibodies were incubated overnight diluted in NGS and washed four times in 30-min intervals with PTx + BSA. Before imaging, samples were washed with PBS and cleared with $70 \%$ glycerol in PBS. Primary antibodies are as follows: 1:1000 rabbit anti-phospho-Histone H3 (Cell Signaling Technology, cat\#: 9701S), 1:800 mouse anti-acetylated tubulin (clone 6-11B-1, Millipore-Sigma, cat\#: MABT868), 1:600 rabbit anti-FMRFamide (Immunostar, cat\#: 20091). Secondary antibodies are as follows: 1:800 goat anti-mouse AlexaFluor 488 (ThermoFisher Scientific, cat\#: A32731), 1:800 goat anti-mouse AlexaFluor 647 (ThermoFisher Scientific, cat\#: A-21235) and 1:800 anti-rabbit AlexaFluor 555 (ThermoFisher Scientific, cat\#: A-21428). To visualize nuclear and F-actin staining, animals were incubated in $5 \mu \mathrm{g} / \mathrm{ml}$ DAPI (ThermoFisher Scientific, cat\#: D3571) and 1:100 AlexaFluor 488 Phalloidin (ThermoFisher Scientific, cat\#: A12379) overnight at $4{ }^{\circ} \mathrm{C}$ in combination with the secondary antibodies.

\section{Gene isolation, riboprobe synthesis and in situ hybridization}

Owenia fusiformis orthologs of elav1 and syt1 were mined from a published transcriptome (SRA\# SRX512807). Fragments of the coding sequences of these genes were amplified to use as templates for RNA probes, using a nested PCR with a T7 universal primer. Genespecific primers with a T7 adapter on the $5^{\prime}$ end of the reverse primer (underlined) were used as follows: elav1 $587 \mathrm{bp}$, forward primer 5'-CCAACAACAGGGCTATCT AAAGG and reverse primer $5^{\prime}$-GCCCCGGCGGAGAC TTGCGATTACTGGT; syt1 $1002 \mathrm{bp}$, forward primer 5'-AGGGATAGTGGCCGTTCTAC and reverse primer 5'-CCCCGGCCGTAACTCTGTACCCGATGC. Animals for in situ hybridization (ISH) were washed from the fixative with PBS +0.1 Tween-20 (PTw), dehydrated in a gradient of methanol and stored at $-20{ }^{\circ} \mathrm{C}$ in $100 \%$ methanol. ISH protocol was carried out as described elsewhere [18], except that animals were permeabilized with $5 \mu \mathrm{g} / \mathrm{ml}$ Proteinase- $\mathrm{K}$ for $90 \mathrm{~s}$ (ThermoFisher Scientific, cat\# AM2548), and hybridized with $1 \mathrm{ng} / \mu \mathrm{l}$ of RNA probe for a minimum of $48 \mathrm{~h}$ at $62^{\circ} \mathrm{C}$. 


\section{Orthology assignment}

Multiple protein alignments (MPA) were constructed with MAFFT v.7 [78] using a L-INS-i method. Poorly aligned regions were removed with gBlocks [79]. Maximum likelihood trees were constructed with RAxML v.8.2.11 [80] using an $\mathrm{LG}+\mathrm{G}+\mathrm{F}$ model and visualized with FigTree (https://github.com/rambaut/figtree/) (Additional file 3: Fig. S2). Accession numbers for the sequences included in the MPAs are listed in Additional file 4: Table S2.

\section{Imaging processing}

Differential interface contrast (DIC) images were taken with a Leica CTRMIC compound scope couple with an Infinity5 camera (Lumenera). Confocal laser scanning microscopy (CLSM) images were taken with a Leica SP5. CLSM Z-stack projections were built with ImageJ2 [81]. To reduce some of the background noise at early stages, the DAPI and phalloidin channels were multiplied and square rooted. This product was subtracted from the original images, as previously described [17]. Autofluorescent dust and precipitates near the animals were digitally removed using Photoshop CC version 14.0 (Adobe Systems, Inc.). DIC images were digitally stacked with Helicon Focus 7 (HeliconSoft). Brightness and contrast were edited with Adobe Photoshop and figures built with Adobe Illustrator CC (Adobe Systems, Inc.).

\section{Supplementary Information}

The online version contains supplementary material available at https://doi. org/10.1186/s13227-021-00176-z.

Additional file 1: Table S1. First appearance of neurons along the anterior(apical)-posterior axis in different groups of Spiralia.

Additional file 2: Figure S1. Culture and artificial fertilization. Adults are (a) relaxed with $\mathrm{MgCl}_{2}$ and (b) stripped from their tubes. (c) Adults are sorted and (d) separated by sex. (e) The sex ratio of adults used in this study was kept very similar. (f) After $27 \mathrm{hpf}$, the larvae were transferred to $600 \mathrm{ml}$ plastic beakers and grown at $15^{\circ} \mathrm{C}$.

Additional file 3: Figure S2. Phylogenetic relationships of $O$. fusiformis Elav1 and Synaptotagmin 1 proteins. (a) RaxML phylogenetic tree of Elav and (b) Synaptotagmin1 of O. fusiformis. (a) Similar to other spiralians, there are two Elav proteins in O. fusiformis. (b) O. fusiformis Synaptotagmin 1 clusters with the Synaptotagmin 1 clade from other spiralians. Refer to the methods for the specifics of the phylogenetic analyses and Additional file 4: Table S2 for the accession numbers used.

Additional file 4: Table S2. Accession numbers of protein sequences used for the alignments of Elav and Synaptotagmin proteins.

\section{Acknowledgements}

We thank the staff at Station Biologique de Roscoff for their help with collections and animal supplies and all members of the Martín-Durán lab for support and valuable comments on the manuscript.

\section{Authors' contributions}

AMCB and JMMD conceived the study. AMCB, OS and JMMD collected and fixed the specimens. AMCB and KG performed the immunostaining.
AMCB cloned and performed phylogenetic analyses and AMCB and JMMD performed expression analyses. AMCB obtained all images. AMCB and JMMD wrote the manuscript. All authors contributed to the interpretation of the data. All authors read and approved the final manuscript.

\section{Funding}

This study was funded by the European Research Council (Starting Grant, Action number 801669) and a Royal Society Grant (RGD 2 R2 180042) to JMMD.

\section{Availability of data and materials}

The sequences of elav1, elav2, synaptotagmin-1 and bruno for Owenia fusiformis are available in GenBank under Accession numbers MW495254MW495257. The raw images used and analyzed during the current study are available from the corresponding author on reasonable request.

\section{Declarations}

Ethics approval and consent to participate

Not applicable.

\section{Consent for publication}

Not applicable.

\section{Competing interests}

The authors declare that they have no competing interests.

Received: 22 February 2021 Accepted: 23 April 2021

Published online: 10 May 2021

\section{References}

1. Laumer CE, Bekkouche N, Kerbl A, Goetz F, Neves RC, Sørensen MV, et al. Spiralian phylogeny informs the evolution of microscopic lineages. Curr Biol. 2015:25:2000-6.

2. Marlétaz F, Peijnenburg KTCA, Goto T, Satoh N, Rokhsar DS. A new spiralian Phylogeny places the enigmatic arrow worms among gnathiferans. Curr Biol. 2019;29(312-318):e3.

3. Henry JQ. Spiralian model systems. Int J Dev Biol. 2014;58:389-401.

4. Seaver EC. Variation in spiralian development: insights from polychaetes. Int J Dev Biol. 2014;58:457-67.

5. Martin-Duran JM, Marletaz F. Unravelling spiral cleavage. Development. 2020;147(1):dev181081.

6. Hejnol A. A twist in time-the evolution of spiral cleavage in the light of animal phylogeny. Integr Comp Biol. 2010;50:695-706.

7. Brun-Usan M, Marín-Riera M, Grande C, Truchado-Garcia M, Salazar-Ciudad I. A set of simple cell processes is sufficient to model spiral cleavage. Dev. 2017:144:54-62.

8. Bleidorn C, Helm C, Weigert A, Aguado MT. Annelida. In: Wanninger A, editor. Evol Dev Biol Invertebr 2 Lophotrochozoa Spiralia. Vienna: Springer; 2015. p. 193-230.

9. Shankland M, Seaver EC. Evolution of the bilaterian body plan: what have we learned from annelids? Proc Natl Acad Sci USA. 2000;97:4434-7.

10. Williams EA, Jékely G. Towards a systems-level understanding of development in the marine annelid Platynereis dumerilii. Curr Opin Genet Dev. 2016;39:175-81.

11. Martín-Durán JM, Vellutini BC, Marlétaz F, Cetrangolo V, Cvetesic N, Thiel $D$, et al. Conservative route to genome compaction in a miniature annelid. Nat Ecol Evol. 2020;5:231-42.

12. Helm C, Beckers P, Bartolomaeus T, Drukewitz SH, Kourtesis I, Weigert $A$, et al. Convergent evolution of the ladder-like ventral nerve cord in Annelida. Front Zool. 2018:15:1-17.

13. Weigert A, Helm C, Meyer M, Nickel B, Arendt D, Hausdorf B, et al. Illuminating the base of the annelid tree using transcriptomics. Mol Biol Evol. 2014;31:1391-401.

14. Helm C, Vöcking O, Kourtesis I, Hausen H. Owenia fusiformis - a basally branching annelid suitable for studying ancestral features of annelid neural development. BMC Evol Biol. 2016:16:1-19.

15. Martín-Durán JM, Pang K, Børve A, Lê HS, Furu A, Cannon JT, et al. Convergent evolution of bilaterian nerve cords. Nature. 2018;553:45-50. 
16. Wilson D. On the mitraria larva of Owenia fusiformis. Philos Trans R Soc Lond B Biol Sci. 1932;221:321-4.

17. Smart TI, Von Dassow G. Unusual development of the mitraria larva in the polychaete Owenia collaris. Biol Bull. 2009;217:253-68.

18. Martín-Durán JM, Passamaneck YJ, Martindale MQ, Hejnol A. The developmental basis for the recurrent evolution of deuterostomy and protostomy. Nat Ecol Evol. 2016;1:1-10.

19. Martín-Durán JM, Vellutini BC, Hejnol A. Embryonic chirality and the evolution of spiralian left-right asymmetries. Philos Trans R Soc B Biol Sci. 2016;371:20150411

20. Boyle MJ, Rice ME. Sipuncula: an emerging model of spiralian development and evolution. Int J Dev Biol. 2014;58:485-99.

21. Martindale MQ, Henry JQ. Modifications of cell fate specification in equalcleaving nemertean embryos: alternate patterns of spiralian development. Development. 1995;121:3175-85.

22. Henry JJ, Martindale MQ. Conservation of the spiralian developmental program: cell lineage of the nemertean, Cerebratuluslacteus. Dev Biol. 1998;201:253-69.

23. Damen P, Dictus WJAG. Cell lineage of the prototroch of Patella vulgata (Gastropoda, Mollusca). Dev Biol. 1994:162:364-83.

24. Damen P, Dictus WJAG. Cell-lineage analysis of the prototroch of the gastropod mollusc Patella vulgata shows conditional specification of some trochoblasts. Roux's Arch Dev Biol. 1994;203:187-98.

25. von Dassow G, Maslakova SA. The trochoblasts in the pilidium larva break an ancient spiralian constraint to enable continuous larval growth and maximally indirect development. Evodevo BioMed Central. 2017;8:1-17.

26. Bird AM. Comparative analysis of cell proliferation patterns in ciliated planktotrophic larvae of marine invertebrates. University of Oregon; 2012.

27. Emlet RB, Strathmann RS. Functional consequences of simple cilia in the mitraria of Oweniids (an anomalous larva of an anomalous polychaete) and comparisons with other larvae. In: Wilson WH, Stricker SA, Shinn GL, editors. Reprod dev mar invertebr. Baltimore: Johns Hopkins University Press; 1994. p. 143-57.

28. Marlow H, Tosches MA, Tomer R, Steinmetz PR, Lauri A, Larsson T, et al. Larval body patterning and apical organs are conserved in animal evolution. BMC Biol. 2014;12:1-17.

29. Vergara HM, Bertucci PY, Hantz P, Tosches MA, Achim K, Vopalensky P, et al. Whole-organism cellular gene-expression atlas reveals conserved cell types in the ventral nerve cord of Platynereis dumerilii. Proc Natl Acad Sci USA. 2017;114:5878-85.

30. Verasztó C, Jasek S, Gühmann M, Shahidi R, Ueda N, Beard JD, et al. Whole-animal connectome and cell-type complement of the threesegmented Platynereis dumerilii larva. bioRxiv. 2020;1-55.

31. Denes AS, Jékely G, Steinmetz PRH, Raible F, Snyman H, Prud'homme B, et al. Molecular architecture of annelid nerve cord supports common origin of nervous system centralization in Bilateria. Cell. 2007;129:277-88.

32. Kumar S, Tumu SC, Helm C, Hausen H. The development of early pioneer neurons in the annelid Malacoceros fuliginosus. BMC Evol Biol. 2020:20:1-21.

33. Meyer NP, Seaver EC. Neurogenesis in an annelid: characterization of brain neural precursors in the polychaete Capitella sp. I. Dev Biol. 2009;335:237-52.

34. Carrillo-Baltodano AM, Boyle MJ, Rice ME, Meyer NP. Developmental architecture of the nervous system in Themiste lageniformis (Sipuncula): new evidence from confocal laser scanning microscopy and gene expression. J Morphol. 2019;280:1628-50.

35. Koushika SP, Lisbin MJ, White K. ELAV, a Drosophila neuron-specific protein, mediates the generation of an alternatively spliced neural protein isoform. Curr Biol. 1996;6:1634-41.

36. Meyer NP, Carrillo-Baltodano A, Moore RE, Seaver EC. Nervous system development in lecithotrophic larval and juvenile stages of the annelid Capitella teleta. Front Zool. 2015;12:1-27.

37. Santagata S, Resh C, Hejnol A, Martindale MQ, Passamaneck YJ. Development of the larval anterior neurogenic domains of Terebratalia transversa (Brachiopoda) provides insights into the diversification of larval apical organs and the spiralian nervous system. EvoDevo. 2012:3:3.

38. Simionato E, Kerner P, Dray N, Le Gouar M, Ledent V, Arendt D, et al. Atonal- and achaete-scute-related genes in the annelid Platynereis dumerilii: insights into the evolution of neural basic-Helix-Loop-Helix genes. BMC Evol Biol. 2008;8:1-13.
39. Kerbl A, Martín-Durán JM, Worsaae K, Hejnol A. Molecular regionalization in the compact brain of the meiofaunal annelid Dinophilus gyrociliatus (Dinophilidae). Evodevo BioMed Central. 2016;7:1-21.

40. Rizo J, Rosenmun C. Synaptic vesicle fusion. Nat Struct Mol Biol. 2008;15:665-74.

41. Gąsiorowski L, Andrikuo C, Janssen R, Bump P, Budd GE, Lowe CJ, et al. A single origin of animal excretory organs. BioRxiv. 2020;1-25.

42. Smith PR, Ruppert EE, Gardiner SL. A deuterostome-like nephridium in the mitraria larva of Owenia fusiformis (Polychaeta, Annelida). Biol Bull. 1987; 172:315-23

43. Helm C, Karl A, Beckers P, Kaul-Strehlow S, Ulbricht E, Kourtesis I, et al. Early evolution of radial glial cells in Bilateria. Proc R Soc B Biol Sci. 2017;284:20170743.

44. Thiel $D$, Bauknecht $P$, Jékely $G$, Hejnol $A$. An ancient FMRFamide-related peptide-receptor pair induces defense behavior in a brachiopod larva. Open Biol. 2017;7:170136

45. Rebscher N, Zelada-González F, Banisch TU, Raible F, Arendt D. Vasa unveils a common origin of germ cells and of somatic stem cells from the posterior growth zone in the polychaete Platynereis dumerilii. Dev Biol. 2007:306:599-611.

46. De Rosa R, Prud'homme B, Balavoine G. Caudal and even-skipped in the annelid Platynereis dumerilii and the ancestry of posterior growth. Evol Dev. 2005;7:574-87.

47. Giani VC, Yamaguchi E, Boyle MJ, Seaver EC. Somatic and germline expression of piwi during development and regeneration in the marine polychaete annelid Capitella teleta. EvoDevo. 2011;2:1-18.

48. Seaver EC, Thamm K, Hill SD. Growth patterns during segmentation in the two polychaete annelids, Capitella sp. I. and Hydroides elegans: comparisons at distinct life history stages. Evol Dev. 2005;7:312-26.

49. Kuroda R, Abe M. The pond snail Lymnaeastagnalis. EvoDevo. 2020;11:1-10.

50. Shibazaki Y, Shimizu M, Kuroda R. Body handedness is directed by genetically determined cytoskeletal dynamics in the early embryo. Curr Biol. 2004;14:1462-7.

51. Freeman G, Lundelius W. Evolutionary specification implications of the mode of D quadrant in coelomates with spiral cleavage. J Evol Biol. 1992:247:205-47.

52. Gonzales EE, Van Der Zee M, Dictus WJAG, Van Den Biggelaar J. Brefeldin $A$ and monensin inhibit the $D$ quadrant organizer in the polychaete annelids Arctonoe vittata and Serpula columbiana. Evol Dev. 2007;9:416-31

53. Pernet $B$, Harris $L H$, Schroeder P. Development and larval feeding in the Capitellid annelid Notomastus cf. tenuis. Biol Bull. 2015;228:25-38.

54. Arenas-Mena C. Sinistral equal-size spiral cleavage of the indirectly developing polychaete Hydroides elegans. Dev Dyn. 2007;236:1611-22.

55. Newby WW. The embryology of the echiuroid worm Urechis caupo. Philadelphia: The American Philosophical Society; 1940.

56. Costello DP, Henley C. Methods for obtaining and handling marine eggs and embryos. 2nd ed. Woods Hole: Marine Biological Laboratory; 1971.

57. Mead AD. The early development of marine annelids. J Morphol. 1897:13:227-326.

58. Lambert JD, Nagy LM. The MAPK cascade in equally cleaving spiralian embryos. Dev Biol. 2003;263:231-41.

59. Treadwell AL. The cytogeny of Podarke obscura Verrill. J Morphol. 1901;17:399-486.

60. Jones C, Stankowich T, Pernet B. Allocation of cytoplasm to macromeres in embryos of annelids and molluscs is positively correlated with egg size. Evol Dev. 2016;18:156-70.

61. Gerould J. The development of Phascolosoma (Studies on the embryology of the Sipunculidae II). Zool Jahrbücher Abteilung Für Anat Und Ontog Der Tiere. 1906;23:77-162.

62. Maslakova SA, Martindale MQ, Norenburg JL. Fundamental properties of the spiralian developmental program are displayed by the basal nemertean Carinoma tremaphoros (Palaeonemertea, Nemertea). Dev Biol. 2004;267:342-60

63. Boyle MJ, Rice ME. Comparative development and the evolution of life history diversity in Sipuncula. In: Boyle MJ, Kawauchi GY, editors. Proc second int symp biol Sipuncula. Washington, D.C.: Smithsonian Institution Scholarly Press; 2018. p. 11-34. 
64. Pernet B, McHugh D. Evolutionary changes in the timing of gut morphogenesis in larvae of the marine annelid Streblospio benedicti. Evol Dev. 2010;12:618-27.

65. McDougall C, Chen WC, Shimeld SM, Ferrier DEK. The development of the larval nervous system, musculature and ciliary bands of Pomatoceros lamarckii (Annelida): Heterochrony in polychaetes. Front Zool. 2006:3:1-14.

66. Anderson D. The comparative embryology of the Polychaeta. Acta Zool. 1966:47:1-42.

67. Page LR. Molluscan larvae: pelagic juveniles or slowly metamorphosing larvae? Biol Bull. 2009;216:216-25.

68. Rouse GW. Trochophore concepts: ciliary bands and the evolution of larvae in spiralian Metazoa. Biol J Linn Soc. 1999:66:411-64.

69. Nielsen C. Trochophora larvae: cell-lineages, ciliary bands, and body regions. 1. Annelida and Mollusca. J Exp Zool Part B Mol Dev Evol. 2004;302:35-68.

70. Fischer AHL, Henrich T, Arendt D. The normal development of Platynereis dumerilii (Nereididae, Annelida). Front Zool. 2010;7:31.

71. Özpolat BD, Handberg-Thorsager M, Vervoort M, Balavoine G. Cell lineage and cell cycling analyses of the $4 \mathrm{~d}$ micromere using live imaging in the marine annelid Platynereis dumerilii. Elife. 2017;6:1-35.

72. Gardiner SL. Fine structure of the ciliated epidermis on the tentacles of Owenia fusiformis (Polychaeta, Oweniidae). Zoomorphologie. 1978:91:37-48.

73. Starunov W, Voronezhskaya EE, Nezlin LP. Development of the nervous system in Platynereis dumerilii (Nereididae, Annelida). Front Zool. 2017;14:1-20

74. Voronezhskaya EE, Tsitrin EB, Nezlin LP. Neuronal development in larval polychaete Phyllodoce maculata (phyllodocidae). J Comp Neurol. 2003;455:299-309.
75. Kristof A, Wollesen T, Wanninger A. Segmental mode of neural patterning in Sipuncula. Curr Biol. 2008;18:1129-32.

76. Kristof A, Maiorova AS. Annelida: sipuncula. In: Schmidth-Rhaesa A, Harzsch S, Purschke G, editors. Struct evol invertebr nerv syst. Oxford: Oxford University Press; 2015. p. 248-53.

77. Kerbl A, Fofanova EG, Mayorova TD, Voronezhskaya EE, Worsaae K. Comparison of neuromuscular development in two dinophilid species (Annelida) suggests progenetic origin of Dinophilus gyrociliatus. Front Zool. 2016:13:1-39.

78. Katoh K, Rozewicki J, Yamada KD. MAFFT online service: multiple sequence alignment, interactive sequence choice and visualization. Brief Bioinform. 2018;20:1160-6.

79. Talavera G, Castresana J. Improvement of phylogenies after removing divergent and ambiguously aligned blocks from protein sequence alignments. Syst Biol. 2007;56:564-77.

80. Stamatakis A. RAxML version 8: a tool for phylogenetic analysis and postanalysis of large phylogenies. Bioinformatics. 2014;30:1312-3.

81. Rueden CT, Schindelin J, Hiner MC, DeZonia BE, Walter AE, Arena ET, et al. Image J2: ImageJ for the next generation of scientific image data. BMC Bioinform. 2017;18:1-26.

\section{Publisher's Note}

Springer Nature remains neutral with regard to jurisdictional claims in published maps and institutional affiliations.
Ready to submit your research? Choose BMC and benefit from:

- fast, convenient online submission

- thorough peer review by experienced researchers in your field

- rapid publication on acceptance

- support for research data, including large and complex data types

- gold Open Access which fosters wider collaboration and increased citations

- maximum visibility for your research: over 100M website views per year

At BMC, research is always in progress.

Learn more biomedcentral.com/submissions 